\title{
Taxonomic Studies of Red Halophilic Bacteria
}

\author{
R. R. COLWELL, ${ }^{1}$ C. D. LITCHFIELD, ${ }^{2}$ R. H. VREELAND, ${ }^{2,3}$ L. A. KIEFER, AND N. E. GIBBONS, $\dagger$ \\ Department of Microbiology, University of Maryland, College Park, Maryland 20742 ${ }^{1}$; Department of \\ Microbiology, Rutgers University, New Brunswick, New Jersey $08901^{2}$; Department of Microbiology, \\ University of Nebraska, Lincoln, Nebraska $68588^{3}$
}

\begin{abstract}
A total of 95 strains of moderately to extremely halophilic bacteria, either from culture collections or freshly isolated, were subjected to taxonomic analysis by the computer method. The culture collection strains were examined in the initial phase of the study, and the fresh isolates were examined later. Three major groupings of these organisms were evident: a group of rodlike halophiles, a group of halotolerant, rod-shaped bacteria, and a less morphologically homogeneous, but taxonomically distinct, cluster of halophilic cocci. The rodlike halophiles could be further subdivided into one cluster containing strains of Halobacterium cutirubrum, which, on initial isolation, are capable of growth on media containing $8 \%$ salt when incubated at elevated temperatures, and another cluster containing strains of Halobacterium salinarium, which have a minimum requirement for $15 \%$ salt irrespective of the temperature of incubation. NRC 34002 and NRC 34001 are proposed as the neotype strains of Halobacterium salinarium and Halobacterium cutirubrum, respectively. The group of halophilic cocci appeared to be less homogeneous, i.e., were less uniform in character frequency of occurrence. Halococcus morrhuae is judged to be the correct name for the halophilic cocci. Results of the taxonomic analyses also indicated that at least two, and perhaps three, biovars comprise $H$. cutirubrum. A comparative study of the halophiles and a sample of $\mathbf{4 8}$ strains of halotolerant streptococci, staphylococci, and micrococci did not reveal any significant interrelationships. The moderate halophiles included in this analysis appear to be taxonomically distinct from the extreme halophiles. Results of lipid and pigment analyses accumulated for the halophilic bacteria support the taxonomic conclusions.
\end{abstract}

Bacteria that require high concentrations of salt for growth have been known for nearly a century. The obligately halophilic bacteria, generally regarded as those which require at least $12 \%$ sodium chloride for growth, are found in the Dead Sea (B. Elazari-Volcani, Ph.D. thesis, Hebrew University, Jerusalem, Israel), on solar salt (30), on salted codfish (20), and in association with other salted products. The classification of these microorganisms has been rather uncertain, and their nomenclature has progressed from the "Microbe du rouge de morue" (29) through $\mathrm{Ba}$ cillus (23), Pseudomonas (20), Bacterium (H. F. M. Petter, Ph.D. thesis, University of Utrecht, Utrecht, the Netherlands), Serratia (30), and Flavobacterium (14). In the seventh edition of Bergey's Manual (5), the obligately halophilic, rod-shaped bacteria were collected under the genus Halobacterium. The halophilic cocci, however, remained dispersed in the genera $\mathrm{Mi}$ crococcus and Sarcina. This arrangement was changed in the eighth edition in which the genera Halobacterium and Halococcus were placed together in part VII, Family 4: Halobacteriaceae (18).

$†$ Deceased, December 1977.
In 1967, Larsen (28) suggested that bacteria which demonstrate a requirement for salt for optimal growth be designated as slight halophiles ( 2 to $5 \% \mathrm{NaCl}$ ), moderate halophiles (5 to $20 \% \mathrm{NaCl}$ ), or extreme halophiles (20 to $30 \%$ $\mathrm{NaCl}$ ). Several studies have shed some light on the specificity of the salt requirement of two halophilic species, Halobacterium cutirubrum and Halobacterium salinarium. Boring et al. (4) investigated the specificity of the $\mathrm{NaCl}$ requirement of $H$. cutirubrum and found that, besides $\mathrm{NaCl}$, other salts, such as $\mathrm{MgCl}_{2}, \mathrm{CaCl}_{2}, \mathrm{Na}_{2} \mathrm{~S}_{2} \mathrm{O}_{3}$, and sodium acetate at concentrations of $3.5 \mathrm{M}$ and $4.0 \mathrm{M}$ will maintain the structural integrity of these organisms. However, only $\mathrm{NaCl}$ was found to support growth of the organism. Kushner (28) suggested that there are sites on the exterior surface of the cell that are specific for $\mathrm{Na}^{+}$for maintenance of integrity. Therefore most of the studies on the halophilic bacteria have been concerned with the nature of their distinctive physiology and metabolism $(2,6,38)$.

It is the purpose of this paper to present the results of taxonomic analyses of data obtained from moderately to extremely halophilic bacteria. The aims of this study were to investigate 
investigate the relationships among the various named strains within the major morphological groups of the halophiles, i.e., rods and cocci, and to determine the phenetic relatedness of culture collection strains and fresh isolates. Information concerning the relationships among the morphological groups of halotolerant, moderately halophilic, and extremely halophilic bacteria was also sought, and the results of these studies are also reported.

\section{MATERIALS AND METHODS}

Bacterial strains. Sixty-nine strains of halophilic bacteria, comprising the collection of halophiles maintained within the Division of Biology, National Research Council of Canada, were used in the initial taxonomic analyses. These strains, together with additional data concerning source, etc., are listed in Table 1. The three reference strains also listed in Table 1 were included in the taxonomic analyses of fresh isolates of halophiles. The analyses were performed as follows. The 69 strains of halophiles were studied at the National Research Council of Canada during 19611963 when one of us (R. R. Colwell) was a Guest Worker with the late N. E. Gibbons. Taxonomic analyses of these strains were carried out at that time. Subsequently, C. D. Litchfield and R. H. Vreeland obtained a set of fresh isolates of halophiles, as described below. Taxonomic data for these isolates were obtained by them using the set of characteristics employed for the collection strains and including more recently devised tests. Both data sets were merged, and the analyses were carried out as described herein.

With the exception of the strains of Micrococcus halodenitrificans, Vibrio costicolus, Pseudomonas beijerinckii, Micrococcus denitrificans, Vibrio halodenitrificans, and Empedobacter marismortui, the strains listed in Table 1 were obligate, extreme halophiles, i.e., they required more than $10 \%$ salt for growth. The strains of the six species listed above grew in media containing from about $2 \%$ to $20 \%$ salt (17).

A comparison of the total set of halophilic strains was made with a set of $\mathbf{4 8}$ strains of staphylococci, micrococci, and streptococci studied in a previous analysis (12; H. Raj, R. R. Colwell, and J. Liston, Bacteriol. Proc., p. 21, 1964). Most of these strains were halotolerant, i.e., able to grow both in the absence of added salt and in the presence of at least $10 \%$ sodium chloride. Included were strains of Staphylococcus aureus and Staphylococcus albus, Staphylococcus epidermidis ATCC 155 and ATCC 10875, Sarcina lutea ATCC 10054, Sarcina flava ATCC 147, Aerococcus viridans ATCC 10400, and Pediococcus cerevisiae ATCC 8081.

The culture collection strains of halophiles were originally isolated at the National Research Council of Canada laboratory (Ottawa) or were obtained from collections in Canada, Norway, Holland, South Africa, and the United States. The materials from which the organisms were isolated were diverse, e.g., salted intestines, western Canadian saline soils, and solar salt.

The culture collection strains were maintained by serial transfer on a medium of the following composition: Casamino Acids (Difco), $5.0 \mathrm{~g}$; yeast extract (Difco), $10.0 \mathrm{~g}$; proteose peptone (Difco), $5.0 \mathrm{~g}$; potas- sium chloride, $2.0 \mathrm{~g}$; trisodium citrate, $3.0 \mathrm{~g}$; magnesium sulfate, $20.0 \mathrm{~g}$; sodium chloride, $200 \mathrm{~g}$; distilled water, $1,000 \mathrm{ml}(\mathrm{pH} 7.2)$. The medium was prepared by mixing the ingredients, adjusting the $\mathrm{pH}$ to 7.8 , heating, filtering, and readjusting the $\mathrm{pH}$ to 7.2 . For solid media, the mixture was prepared with $2.0 \%$ (wt) vol) agar. Incubation of the cultures was at $37^{\circ} \mathrm{C}$.

Tests and test methods. All of the strains were examined for motility and for morphological features using phase-contrast microscopy. The cells were suspended in a $20 \% \mathrm{NaCl}$ solution $(4 \% \mathrm{NaCl}$, in the case of the moderate halophiles). The Gram stain method used was that of Dussault (13).

Preparation of the inocula and details of the gelatin liquefaction, starch hydrolysis, indole and hydrogen sulfide production, and nitrate reduction tests have been given previously $(13,17)$.

Tests for the ability of the strains to grow at $\mathrm{pH} 4.0$, $5.5,7.2,8.0$, and 8.5 , at sodium chloride concentrations of $2.5,5.0,7.5,10.0,15.0$, and $20 \% \mathrm{NaCl}$, and at temperatures of $35,37,40,45$, and $50^{\circ} \mathrm{C}$ were carried out using the basal medium given above, but with appropriate modification.

Susceptibility to antibacterials was tested by the disk method (BBL Microbiology Systems, Cockeysville, Md.) with the following antibiotics: penicillin $G$ $(10 \mathrm{U})$; chloromycetin $(30 \mu \mathrm{g})$; erythromycin $(15 \mu \mathrm{g})$; kantrex $(30 \mu \mathrm{g})$; novobiocin $(30 \mu \mathrm{g})$; polymyxin B $(300$ $\mathrm{U})$; terramycin $(30 \mu \mathrm{g})$; tetracycline $(30 \mu \mathrm{g})$; aureomycin $(30 \mu \mathrm{g})$; and dihydrostreptomycin $(10 \mu \mathrm{g})$.

The catalase, blood hemolysis (5\% [vol/wt] blood agar), Koser and Simmons citrate, and litmus milk tests were carried out using published methods (37). The presence of phenylalanine deaminase, arginine dihydrolase, lysine and ornithine decarboxylases (15), and lipase (Tweens 40, 60, and 80) (34) was tested for each strain. The oxidase reaction employed for testing the 47 culture collection isolates was the described by Kovacs (25); for the fresh isolates, the cytochrome oxidase test (Patho-Tech strips; Warner-Lambert Co., Morris Plains, N.J.) was used. Production of hydrogen sulfide was determined by the miniature-tube method (13). The ability to produce visible growth and appropriate reaction on the following special media (Difco Laboratories, Detroit, Mich.) was also determined: Pseudomonas F and P agar; Streptococcus faecalis medium; Chapman-Stone agar; ethyl violet azide broth; mannitol salt agar; tellurite glycine agar; and Staphylococcus 110 medium. These were prepared with $20 \% \mathrm{NaCl}$, with the exception of the Staphylo. coccus 110 medium, which was prepared both with $(20 \%[\mathrm{wt} / \mathrm{vol}])$ and without the addition of sodium chloride.

The medium of Board and Holding (3) was employed to observe the ability of the halophiles to use inorganic nitrogen as a sole source of the element as well as to determine oxidative utilization of glucose. Utilization of five carbohydrates, glucose, glycerol, xylose, lactose, and sucrose, was determined manometrically. Carbohydrate utilization data included here were from studies carried out at the National Research Council by Baxter and Gibbons and were included in an earlier study summarized by Larsen (27).

Isolation of strains. The fresh isolates included 23 strains obtained from a solar salt facility in Bonaire, 
Netherland Antilles, during 1974 and 1975. The initial isolation medium for these strains was prepared as two separate solutions. Solution A contained $25 \%$ (wt/vol) solar salt; the $\mathrm{pH}$ of this solution was adjusted to 11 with $1 \mathrm{~N} \mathrm{NaOH}$ prior to autoclaving, after which $0.75 \%$ vitamin-free casein (Difco) was added. The mixture was incubated overnight at $30^{\circ} \mathrm{C}$, and the $\mathrm{pH}$ was then adjusted to 7.9 . Solution $\mathrm{B}$ also contained $25 \%$ solar salt (wt/vol), but this was supplemented with $0.1 \%$ yeast extract (Yeast Products, Paterson, N.J.), 0.3\% sodium citrate, $2.0 \% \mathrm{MgSO} \cdot 7 \mathrm{H}_{2} \mathrm{O}$, and $0.005 \%$ ferric ammonium sulfate (Fisher Chemical Co.). The solution was brought to $\mathrm{pH} 7.9$ with $1 \mathrm{~N} \mathrm{NaOH}$ and autoclaved. Just before use, solution $\mathrm{A}$ and solution $\mathrm{B}$ were mixed in a 1:1 ratio. When solid media were used, agar (Difco) was added, at $2 \%$ concentration, to solution B prior to sterilization. Twenty-two of the 23 strains required at least $8 \%$ solar salt for growth at $23^{\circ} \mathrm{C}$, whereas only one red halophilic coccus had this requirement for salt. The saltern density of the source material and the characteristics of the strains recorded at the time of isolation are given in Table 2.

Maintenance medium. The medium of Abram and Gibbons (1) was modified to contain a lower concentration of nutrients. The modified medium provided more rapid growth and longer viability of the freshly isolated halophiles. Thus, cultures of these strains were maintained on the following medium: yeast extract (Yeast Products), $1.0 \mathrm{~g}$; Casamino Acids with vitamins (Difco), $7.5 \mathrm{~g}$; $\mathrm{K}_{2} \mathrm{HPO}_{4}$ (Merck \& Co., Rahway, N.J.), $7.5 \mathrm{~g}$; proteose peptone no. 3, $5.0 \mathrm{~g}$; sodium citrate, $3.0 \mathrm{~g} ; \quad \mathrm{MgSO}_{4} \cdot 7 \mathrm{H}_{2} \mathrm{O}, 20.0 \mathrm{~g}$; $\mathrm{Fe}\left(\mathrm{NH}_{4}\right)_{2} \mathrm{SO}_{4} \cdot 6 \mathrm{H}_{2} \mathrm{O}, 0.05 \mathrm{~g}$; solar salt (Antilles Salt Co., Bonaire, Netherlands Antilles), 8 or $20 \%$ (wt/vol); distilled water, 1 liter, $\mathrm{pH} 8.0 \pm 0.1$. The solid form of the medium contained $2 \%$ (wt/vol) agar (Difco). The medium was prepared, the $\mathrm{pH}$ was adjusted, and the medium was sterilized. Filtration of the medium was not necessary, since the precipitate was found not to interfere with the reading of the test results. Unless specified otherwise, the cultures were incubated at $30^{\circ} \mathrm{C}$, close to their environmental temperature.

The strains added to the test set, along with the 23 fresh isolates, were Halobacterium cutirubrum NRC 34001, Halobacterium salinarium NRC 34002, and Halococcus morrhuae NRC 16015, supplied by D. J. Kushner (see Table 1).

Each of the fresh isolates was examined in a wet mount to determine cell shape, motility, and cellular arrangement. The Gram reaction of each of the fresh isolates was determined by washing the smear with $20 \%$ (wt/vol) solar salt solution between staining with crystal violet, iodine fixation, and decolorization. Decolorization was accomplished using acetone-ethanol (50:50, vol/vol) followed by a distilled water wash and counterstaining with safranin. The flagella were observed using the Leifson staining technique (36), which employs a tannic acid-basic fuchsin (2:1, vol/vol) mixture. Tannic acid was prepared daily, whereas basic fuchsin was prepared every other day. The solutions were mixed and allowed to stand undisturbed for $2 \mathrm{~h}$ before use.

Solid casein medium prepared at the appropriate salt concentrations was used for recording colony characteristics, protein hydrolysis, catalase production, and growth with $10 \% \mathrm{CO}_{2}$. Oxygen requirements were also determined in thioglycolate medium (Difco); the tubes were read after incubation at $37^{\circ} \mathrm{C}$ for 28 days.

Each of the fresh isolates was tested for ability to grow in maintenance medium at selected temperatures

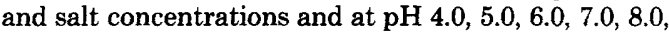
and 9.0. The solar salt concentrations tested were 0 , $3.5,8.0,15.0,20.0$, and $32 \%$ (wt/vol), and for each salt concentration, the temperatures of incubation were 4 , $15,23,30,37$, and $45^{\circ} \mathrm{C}$. At the completion of the temperature/salt studies, which were usually 28 days in duration, all cultures lacking visible growth were transferred to fresh maintenance medium and incubated at $30^{\circ} \mathrm{C}$ for 28 days to determine whether the temperature/salt combination being tested was lethal or inhibitory; i.e., the appearance of growth after transfer indicated inhibition.

Carbohydrate utilization in the case of the fresh isolates was studied using the bromothymol blue medium of Holding and Collee (21) or phenol red broth base (Difco). The basal media were prepared at the appropriate salt concentrations and supplemented, before sterilization, with $0.5 \%$ (wt/vol) of the following carbon sources: sucrose, glycerol, mannose, cellobiose, glucose, or lactose.

Starch hydrolysis was detected in all cases by noting cleared zones on agar plates flooded with Gram iodine after incubation of the test cultures on a $0.5 \%$ cornstarch medium (37). In addition to the detection of proteolysis by the use of casein plates, the ability to hydrolyze gelatin (Difco) was also tested (37).

Other biochemical tests, performed using the Patho-Tech Rapid I.D. System (Warner-Lambert), included: cytochrome oxidase, nitrate reduction, phenylalanine deaminase, lysine decarboxylase, $\mathrm{H}_{2} \mathrm{~S}$ production from cysteine, indole production, Voges-Proskauer test, urease production, esculin hydrolysis, malonate utilization, ornithine decarboxylase, and $\beta$-galactosidase synthesis. The test strips were adopted after preliminary testing indicated frequent interference of test results from the high salt concentrations, especially in the case of the nitrate, indole, urease, amino acid decarboxylase, and phenylalanine deaminase tests.

The antibacterial compounds used for testing the 23 fresh isolates were those most useful for characterizing halophiles: penicillin $\mathrm{G}(10 \mathrm{U})$, tetracycline (30 $\mu \mathrm{g})$, dihydrostreptomycin $(10 \mu \mathrm{g})$, chloromycetin (30 $\mu \mathrm{g})$, ampicillin $(30 \mu \mathrm{g}), 0 / 129$ vibriostat (crystalline), and $\mathrm{HgCl}_{2}(0.1 \mathrm{ml}$ at 1:5,000 dilution) placed on sterile disks.

Data processing. The data for all of the strains (69 collection strains, 23 fresh isolates, and 3 reference strains) were coded and transferred to IBM cards for processing. Similarity values for strain-by-strain comparisons were computed. The initial (sorted) output was scanned for clustering of related strains. The coding methods and programs have been published elsewhere $(7,9)$.

The homogeneity of the groups formed by computer analysis was further tested by the method described by Quadling and Colwell (32). An IBM 1620 model I 40,000 K (Computation Center, National Research Council, Canada) was used in the preliminary analyses, and a UniVac 1108 (Computation Center, University of Maryland, College Park) was used in the final steps of the data processing. 
TABLE 1. Laboratory strains of halophiles included in this study

Strain $\quad$ Source

N-1(36), ${ }^{a} \mathrm{~N}-2(37), \mathrm{N}-3(38), \mathrm{N}-4(39), \mathrm{N}-5(40), \mathrm{N}-7(41), \quad$ N. E. Gibbons; from Newfoundland N-8(42)

4b2(43), 3-3(44)

Halobacterium halobium M (45)

Sarcina morrhuae M (46)

Halobacterium halobium P (47)

$3(48), R-4(49), 5(50), 6(51), R-7(52)$

Sarcina littoralis 8 (53)

Halobacterium cutirubrum 9 (54)

Halobacterium salinarium 10 (55)

A-2C(56), A-7(57), A-14(58), A-18(59), A-22(60), A24(61), A-31C(62), A-31r(63), A-32(64)

SC-1(65), SC-2(66), SC-4(67)

Bacterium halobium 6 (68)

Pseudomonas cutirubra L (69)

Sarcina morrhuae 9.5 (70)

Sarcina morrhuae V (71)

Micrococcus morrhuae Delft (72)

Micrococcus morrhuae Dead Sea (73)

Bacterium halobium 6.31.1(74), 6.31.2(75), 6.31.3(76), $6.31 .4(77), \quad 6.31 .6(78), \quad 6.31 .7(79), \quad 6.31 .8(80)$, $6.31 .9(81), 6.31 .10(82)$

Sarcina sp. H-1(83), H-2(84), H-8(85)

Micrococcus sp. H-5(86)

Sarcina littoralis $\mathrm{H}-9(87)$

Halobacterium minuteum $\mathrm{H} 24 \mathrm{~T}(88)$

Halobacterium gibbonsii H45T, H45(89)

Pseudomonas cutirubrum (sic) $\mathrm{H} 48(90)$

Sarcina morrhuae (91)

Micrococcus morrhuae (92)

Halobacterium halobium (93)

Sarcina gigantea (94)

Halobacterium trapanicum (95)

Sarcina sreenivasani (96)

Micrococcus halodenitrificans 79 (97)

Vibrio costicolus 75 (98)

Pseudomonas beijerinckii ATCC 19372 (99)
N. E. Gibbons; isolated from Western Canadian saline soils

D. A. A. Mossel, Utrecht, Zeist, The Netherlands

A. Pijper, South Africa; isolated from solar salt

Halifax or Gaspé solar salts

A. G. Lochhead; isolated from salted hides

Norway; salt, salted fish

N. E. Gibbons; isolated from sausage casings

P. A. Zahl, Haskins Laboratory, New Haven, Conn.; isolated in Bahamas from gut of hermit crab

S. H. Hutner; isolated by A. G. Lochhead from salted buffalo hide

S. H. Hutner; from B. Volcani collection

B. Volcani

S. H. Hutner; originally from Delft collection

N. E. Gibbons; cultures received from R. Venkataraman

J. M. F. Holtz, Delft; from salted hides

H. F. M. Petter, Delft; from salted herring

H. F. M. Petter, Delft; from trapani salt

V. Bertullo, Montevideo University; isolated from salted fish

N. E. Gibbons

J. Robinson; isolated from bacon-curing brines, Hull, Quebec

T. Hoff, Delft; isolated from salted beans 
TABLE 1. (continued)

\begin{tabular}{|c|c|}
\hline Strain & Source \\
\hline Micrococcus denitrificans (100) & M. W. Beijerinck, Delft \\
\hline $\begin{array}{l}\text { Vibrio costicolus (101) } \\
\text { Vibrio halodenitrificans }(102)\end{array}$ & $\begin{array}{l}\text { R. Buttiaux, Institut Pasteur, Lille, France; isolated } \\
\text { from ham-curing brines }\end{array}$ \\
\hline Empedobacter marismortui no. 272 (103) & $\begin{array}{l}\text { J. Brisou, Poitiers, France; isolated from saline lake, } \\
\text { North Africa }\end{array}$ \\
\hline \multicolumn{2}{|l|}{ Reference strains: } \\
\hline $\begin{array}{l}\text { Halobacterium cutirubrum NRC } 34001 \text { (104) } \\
\text { (ATCC 33170) }\end{array}$ & D. J. Kushner, Ottawa [Lochhead 63-R2 = DSM 669] \\
\hline $\begin{array}{l}\text { Halobacterium salinarium NRC } 34002 \text { (105) } \\
\text { (ATCC 33171) }\end{array}$ & D. J. Kushner, Ottawa [Lochhead 91-R6] \\
\hline
\end{tabular}

${ }^{a}$ Numbers in parentheses refer to strain numbers represented in Fig. 8.

TABLE 2. Initial salt concentration and colony characteristics of halophilic strains freshly isolated from a solar salt facility

\begin{tabular}{|c|c|c|c|}
\hline $\begin{array}{l}\text { Isolation } \\
\text { date }\end{array}$ & Strain & $\begin{array}{c}\text { Percent } \\
\text { salt in } \\
\text { isolation } \\
\text { pan }\end{array}$ & $\begin{array}{l}\text { Colonial } \\
\text { color }\end{array}$ \\
\hline June 1974 & $\begin{array}{l}\text { 1H1 } \\
1 \mathrm{H} 4 \\
1 \mathrm{H} 7 \\
1 \mathrm{H} 8 \\
1 \mathrm{H} 10 \\
1 \mathrm{H} 16\end{array}$ & $\begin{array}{l}16.8 \\
20.2 \\
26.7 \\
26.7 \\
32.58 \\
26.7\end{array}$ & $\begin{array}{l}\text { Red orange } \\
\text { Red } \\
\text { Red } \\
\text { Light pink } \\
\text { Red } \\
\text { Red }\end{array}$ \\
\hline December 1974 & $\begin{array}{l}2 \mathrm{H} 2 \\
2 \mathrm{H} 7 \\
2 \mathrm{H} 8 \\
2 \mathrm{H} 13\end{array}$ & $\begin{array}{l}24.1 \\
24.1 \\
24.1 \\
32.6\end{array}$ & $\begin{array}{l}\text { Pale red } \\
\text { Red } \\
\text { Red } \\
\text { White }\end{array}$ \\
\hline January 1975 & $\begin{array}{l}3 \mathrm{H} 16 \\
3 \mathrm{H} 18 \\
3 \mathrm{H} 20 \\
3 \mathrm{H} 21 \\
3 \mathrm{H} 22 \\
3 \mathrm{H} 23 \\
3 \mathrm{H} 24 \\
3 \mathrm{H} 25 \\
3 \mathrm{H} 27 \\
3 \mathrm{H} 28 \\
3 \mathrm{H} 29 \\
3 \mathrm{H} 30^{a} \\
3 \mathrm{H} 31\end{array}$ & \begin{tabular}{|c|}
24.1 \\
32.6 \\
26.7 \\
26.7 \\
32.5 \\
32.5 \\
32.5 \\
32.6 \\
32.5 \\
32.5 \\
$\mathrm{v}^{b}$ \\
26.7
\end{tabular} & $\begin{array}{l}\text { White } \\
\text { Red } \\
\text { Pink } \\
\text { Cream } \\
\text { Cream } \\
\text { Cream } \\
\text { Light pink } \\
\text { Red } \\
\text { Dark red } \\
\text { Dark red } \\
\text { Light pink } \\
\text { Light pink } \\
\text { White }\end{array}$ \\
\hline
\end{tabular}

${ }^{a}$ The only one of these isolates never to demonstrate rod-shaped morphology; occurs as a single coccus.

${ }^{b} v$, Variable salt concentration because of mixing fresh seawater with brine washing water.

Computations were also made to assess the relationships of the halophiles to the halotolerant staphylococci and streptococci studied in earlier taxonomic investigations (12, 32; Raj, Colwell, and Liston, unpublished data). Similarity values were computed for a sample of 69 strains of streptococci. In addition, the Jaccard and matching coefficients (7) for the 96 isolates were compiled, and the two sets of data were merged to produce a full $S_{M}$ matrix. These computations were performed using the IBM 375 computer and the University of Maryland GTP-2 numerical taxonomy program.

\section{RESULTS}

The initial sorting of a sample of 47 culture collection strains of halophiles, following the method of Colwell and Liston (9), indicated two distinctly separate clusters, one of halophilic rodlike bacteria and the other of halophilic cocci. On the basis of the calculated similarity values, it was difficult to place five of the strains in either of the two major groupings. Strains A-2C, A-31C (colorless contaminants picked up in earlier studies with the halophiles [17]), N-3, and Bacterium halobium no. 6 (Bahamas) had overall similarity values of $<70 \%$ with the halophilic rodlike cluster; similarly, strain A-7 grouped with the halophilic cocci at $<63 \% S$.

The mean similarity $(\bar{S})$, employing the Jaccard coefficient, for the total sample of 47 strains was $63 \pm 14 \%$. Of 185 features scored, $\bar{N}_{s}=43$, $\bar{N}_{d}=25$, and $\bar{N}_{o}=117$, where $\bar{N}_{s}=$ mean number of shared features, $\bar{N}_{d}=$ mean number of features positive in one strain but not in both of a comparison, and $\bar{N}_{o}=$ mean number of features present in neither strain; $\bar{M}=86 \pm 6 \%(\bar{M}=$ matching coefficient [35]).

The values for the group of halophilic rodlike bacteria (comprising 30 strains and including unidentified isolates) and for strains identified as members of $H$. halobium, $H$. cutirubrum, $B$. halobium, or Pseudomonas cutirubra, were as follows: $\bar{S}=78 \pm 6 \% ; \bar{N}_{s}=51 ; \bar{N}_{d}=14 ; \bar{N}_{o}=$ 120 ; and $\bar{M}=92 \pm 2 \%$.

The halophilic rodlike strains that did not share high similarities with the major cluster formed in this analysis were not homogeneous 
among themselves $(S<50 \%)$. However, including these strains in the large cluster did decrease the overall intragroup similarity $(\bar{S}=73 \pm 11 \%$; $\bar{N}_{s}=48 ; \bar{N}_{d}=18 ; \bar{N}_{o}=118 ;$ and $\bar{M}=90 \pm 5 \%$ ), where $S=$ similarity, $N_{s}=$ number of shared characteristics, $N_{d}=$ number of dissimilar characteristics, $N_{o}=$ number of characteristics present in neither strain, and $M=$ matching coefficient (9).

The cluster of halophilic cocci was relatively less homogeneous $\left(\bar{S}=70 \pm 7 \% ; \bar{N}_{s}=41 ; \bar{N}_{d}=\right.$ 18; $\bar{N}_{o}=126$; and $\bar{M}=90 \pm 3 \%$ ). Adding the single strain A-7 to the micrococci cluster reduced the overall intragroup similarity to $\bar{S}=$ $67 \pm 9 \%$.

After the data were plotted by computer and the methods described by Quadling and Colwell
(32) were followed in further analysis of the data, a clustering of the halophilic rods was evident. A separate clustering of the micrococci from the rodlike bacteria was discernible (Fig. 1). In Fig. 2 , the 30 strains are shown as a relatively homogeneous clustering within the range of $\bar{S}$ from 69 to $83 \%$. Figure 3 presents similar data for the halophilic micrococci. Typical morphology, i.e., fine structure of the halophilic rods and cocci as determined by examination of ultrathin sections examined under the electron microscope, is shown in Fig. 4 and 5.

The frequency of occurrence of features within the cluster was calculated (8) (Tables 2 to 4). The features determined for both rods and cocci are listed in Tables 3 and 4 . These tables also provide a listing of the features useful for de-

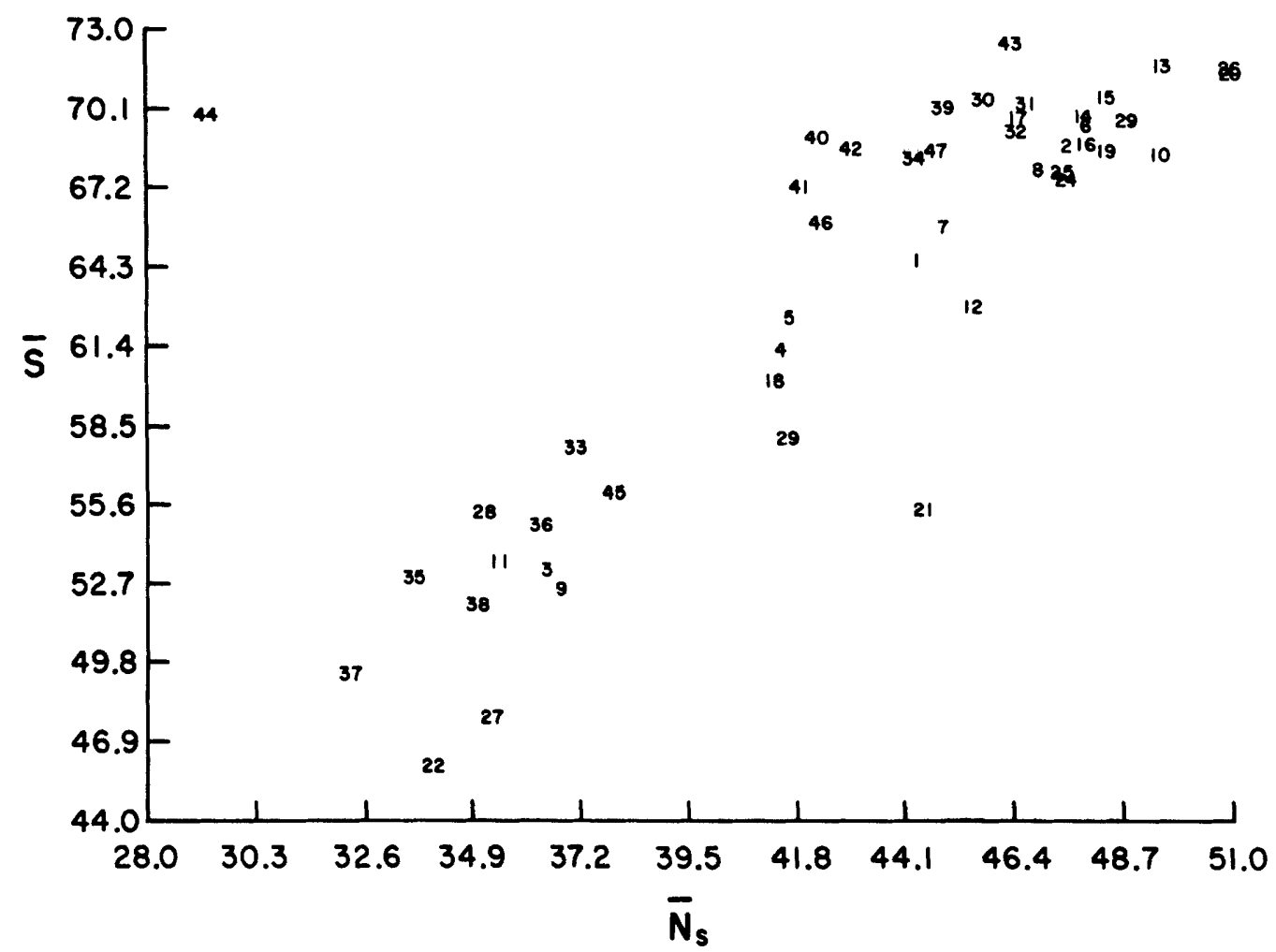

\section{HALOPHILIC BACTERIA}

Fig. 1. On-line automatic plotting output from sorting of 47 strains of halophilic bacteria. See Table 1 for details of source, etc. Code: $1, N-1 ; 2, N-2 ; 3, N-7 ; 4, N-8 ; 5,4 b 2 ; 6, H$. halobium $M ; 7, H$. halobium P;8, 3;9, $R-4 ; 10,5 ; 11,6 ; 12, R 7 ; 13, H$. cutirubrum $9 ; 14, H$. salinarium $10 ; 15, A-18 ; 16, A-22 ; 17, A-24 ; 18, A-32 ; 19$, SC-1; 20, SC-2; 21, SC-4; 22, P. cutirubra L; 23, B. halobium 6.31.1; 24, B. halobium 6.31.2; 25, B. halobium $6.31 .3 ; 26, B$. halobium 6.31.4; $27, B$. halobium 6.31.6; 28 , B. halobium 6.31.7; 29, B. halobium $6.31 .9 ; 30, B$. halobium 6.31.10; 31, N3; 32, A-2C; 33, A-31C; 34, B. halobium 6; 35, N.4 (coccus); $36, N-5$ (coccus); $37,3-3$ (coccus); 38, S. morrhuae $M$ (coccus); 39, S. littoralis 8 (coccus); 40, A-14 (coccus); 41, A-31r (coccus); $42, S$. morrhuae 9.5 (coccus); 43, S. morrhuae V (coccus); 44, M. morrhuae Delft (coccus); 45, M. morrhuae Dead Sea (coccus); 46, B. halobium 6.31 .8 (coccus); 47, A-7. 


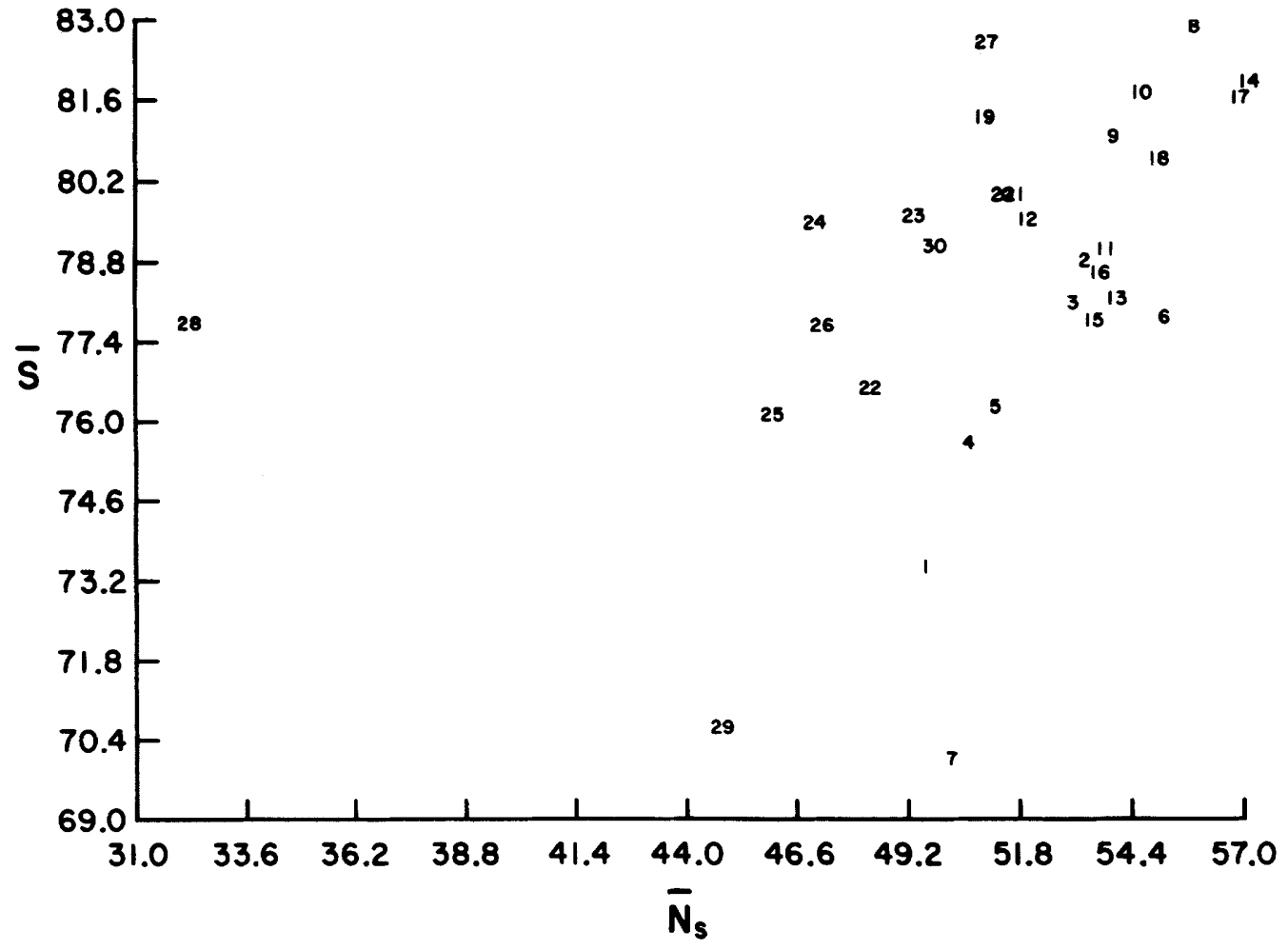

\section{HALOPHILIC RODS}

FIG. 2. On-line automatic plotting output from sorting of strains of halophilic rodlike bacteria. For code, see Fig. 1.

scribing the two major clusters, i.e., rods and cocci.

In an effort to confirm the identity of the named strains, the Halobacterium and the halophilic Micrococcus strains were further studied by subjecting an additional 24 strains of halophilic rods and cocci, including eight moderately halophilic strains, to those tests suggested from the data of Tables 3 and 4 to be of high information value. Additional computation was performed by computer to assess similarities of the final sample set, and the results of the sorting are presented in Fig. 6.

From this analysis, it was observed that the moderately halophilic bacteria did not cluster with either of the previously formed major clusters of rods and cocci. The strains of $M$. denitrificans, $M$. halodenitrificans, Empedobacter marismortui, Vibrio costicolus (Inst. Pasteur strain), and Vibrio halodenitrificans appeared distinct from Vibrio costicolus 75 and the strain of $P$. beijerinckii, the latter two being of sufficiently high similarity, one to the other, to suggest species relationship.
A clustering of strains did occur $(H$. halobium P through, and including, B. halobium 6; Fig. 6). This suggested high intragroup homogeneity. Strains A-2C, N-3, and A-31C grouped only at low $\bar{S}$ values. Strain Halobacterium gibbonsii $\mathrm{H} 45$ and $\mathrm{H} 45 \mathrm{~T}$ were highly related $(\bar{S}=92 \%)$. The strains of $H$. gibbonsii, Halobacterium trapanicum, H. halobium, Sarcina morrhuae (which, incidentally, in our hands was of a rodlike morphology), and P. cutirubrum (sic) $\mathrm{H} 48$ were not unequivocably incorporated into the clusters formed in the initial analyses.

The grouping, by sorted $\bar{S}$ values, of halophilic strains from Micrococcus sp. H-5 through and including strain 3-3 (see Fig. 6) consisted of coccus-shaped microorganisms of similar morphology and physiology.

The relationships of the 21 halophilic cocci clustered on the basis of features studied in the initial analyses were further investigated by subjecting these strains to tests devised for isolation and identification of halotolerant strains of staphylococci, micrococci, and enterococci. Data for the latter group and for the halophilic micro- 


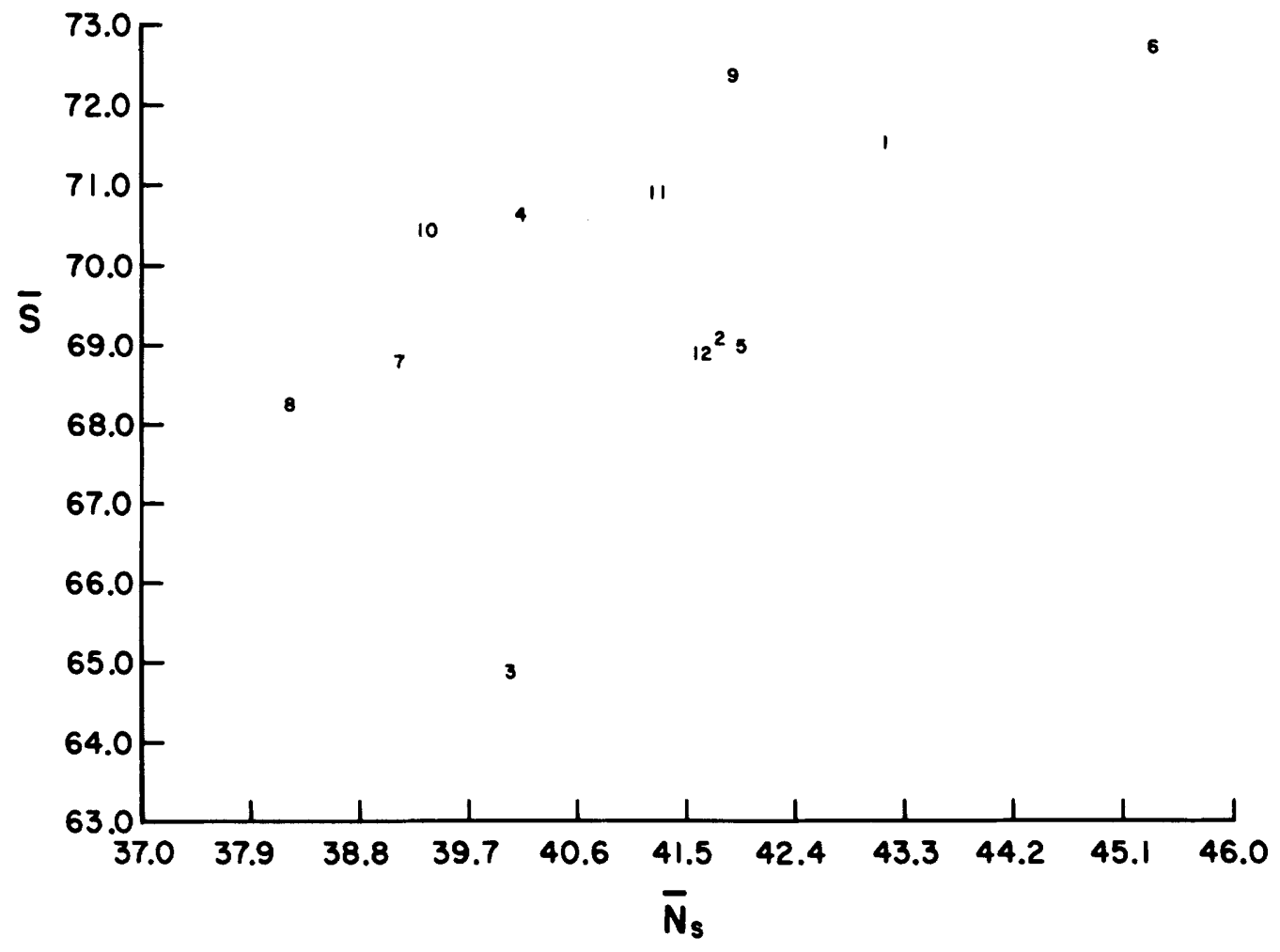

\section{HALOPHILIC MICROCOCCI}

FIG. 3. On-line automatic plotting output from sorting of halophilic micrococci. Code: $1, N-4 ; 2, N-5 ; 3,3$ 3; 4, S. morrhuae M; 5, S. littoralis 8; 6, A-14; 7, A-31r; 8, S. morrhuae 9.5; 9, S. morrhuae V; 10, M. morrhuae Delft; 11, M. morrhuae Dead Sea; 12, B. halobium 6.31.8.

cocci (including moderately halophilic strains from analyses discussed above) were pooled, and common similarity values were computed. $S$ values for intergroup strain comparisons were $<40 \%$. These low values suggested that little or no significant taxonomic relationship existed between the halotolerant staphylococci, micrococci, and enterococci. Thus, further study to extend this line of investigation did not appear to be promising.

The initial sorting of $\bar{S}$ values by the method of Colwell and Liston (9) for the sample set of 47 strains provided a distribution of cultures into morphologically and physiologically similar subsets, one for halophilic rods, the other for halophilic cocci.

The strain characteristics were analyzed according to the subgroupings obtained (Tables 3 , 4,5 , and 6 ). Of the set of 47 strains of extreme halophiles examined initially, certain characteristics were expressed by all the strains. All grew well in a medium to which $20 \% \mathrm{NaCl}$ was added (at pH 7.2 and at $35^{\circ} \mathrm{C}$ incubation temperature).
All produced abundant growth in nitrate broth without added $\mathrm{Mg}^{2+}$, but none reduced the nitrate to gaseous end products. The 47 strains were catalase positive. Other features of high frequency of occurrence were: ability to produce hydrogen sulfide from peptones, sodium thiosulfate, and cysteine; liquefaction of gelatin; and production of indole. All of the strains were susceptible to novobiocin, but none was susceptible to erythromycin. Susceptibility to penicillin, chloromycetin, and terramycin was not frequently demonstrated ( $<7 \%$ of the total sample).

In general, litmus milk was not attacked. No growth occurred in halophile medium adjusted to an initial $\mathrm{pH}$ of 4.0. Xylose was utilized by few strains $(6 \%)$, whereas sucrose and lactose were not utilized by any of the strains. Urease, phenylalanine deaminase, lysine decarboxylase, and ornithine decarboxylase could not be detected by the methods employed.

The group of rod-shaped halophiles demonstrated the characteristic morphology of halophiles described by previous investigators (19), 


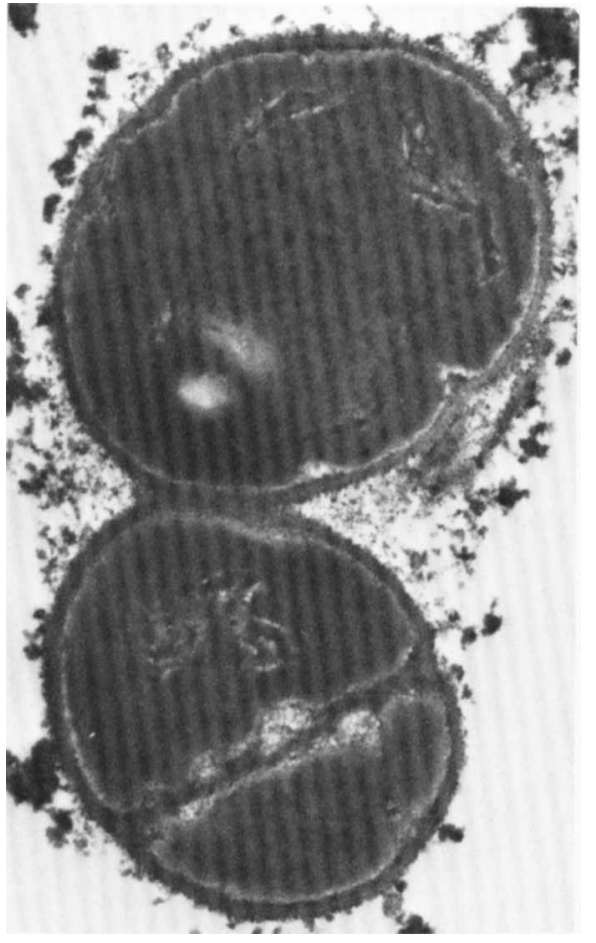

FIG. 4. Ultrastructure of halophilic cocci determined by electron microscopy. Sarcina morrhuae $\mathrm{OH}$ 523 (Vol 5.30); $\times 37,000$.

i.e., stout $(0.6$ to $1.0 \mu \mathrm{m})$, long rods $(>1 \mu \mathrm{m})$ occurring predominantly as single cells, with pointed or tapered ends. Some oval forms and pleomorphic cells were observed. The pleomorphism of extreme halophiles has been found to be associated, at least in part, with sodium chloride concentration (1). About $25 \%$ of the strains in the sample were motile. Flagella were observed on the motile cells.

The cocci were large $(0.6$ to $2.0 \mu \mathrm{m}$ in diameter) spheres or oval-shaped cells occurring as pairs or in clusters.

On agar the halophiles produced small colonies $(<2 \mathrm{~mm}$ in diameter) with an entire edge and a nondiffusible, reddish pigment. The rodshaped halophiles produced a translucent, pigmented colony, whereas the cocci formed opaque, pigmented colonies on agar. In broth the cocci produced a slight, even turbidity, and the rodlike bacteria produced a moderate, even turbidity, occasionally with a surface ring on the sides of the tube.

In general, the rods were distinguished, physiologically, from the cocci in having a wider initial pH range (ca 5.5 to 8.5) for growth, in possessing an arginine dihydrolase and a gelatinase, and in demonstrating a higher frequency of susceptibility to polymyxin B, tetracycline, and dihydrostreptomycin. These features were not absolute, however, as $25 \%$ of the coccal cultures were arginine dihydrolase positive and $75 \%$ were gelatinase positive. About $67 \%$ of the rodshaped halophiles hydrolyzed casein, but none of the cocci demonstrated this feature. All of the coccal strains were lipolytic, but none of the halophilic rod-shaped strains demonstrated a lipase on the Tween 80 medium, and fewer than $20 \%$ did so on the Tween 40 and Tween 60 media.

Starch hydrolysis was a rare feature in the group of rod-shaped organisms, but $50 \%$ of the cocci were able to hydrolyze starch. Neither the rod nor the coccus subset demonstrated susceptibility to penicillin, chloromycetin, terramycin, aureomycin, or erythromycin.

When 32 freshly isolated strains were subjected to a battery of tests similar to those applied to the collection strains, and when the resultant data were analyzed by single linkage analysis, the similarity matrix in Fig. 7 was generated. Although all isolates were originally obtained from environments containing $>16 \%$ (wt/ vol) salt and from media containing 20 to $25 \%$ salt, a large group of nonpigmented, highly halotolerant isolates was obtained. Those organisms that are nonpigmented and do not require salt can be clearly separated from the pigmented halophiles (Fig. 7) and are placed in group I. This highly salt-tolerant group of nine isolates will be described in a subsequent paper (Litchfield and Vreeland, manuscript in preparation). The remaining strains demonstrated an overall similarity, $>70 \%$, indicating a high degree of phenetic relatedness. These halophiles can be subdivided into three major groups, the first of which consists of $1 \mathrm{H8}$, the NRC strain (541) of H. cutirubrum, 3H23, 3H $31,2 \mathrm{H} 13,3 \mathrm{H} 22,3 \mathrm{H} 21$, and $3 \mathrm{H} 16$. The second group contained $\mathrm{H}$. salinarium 542, 3H27, 3H28, $2 \mathrm{H} 7,1 \mathrm{H} 7,1 \mathrm{H} 16,1 \mathrm{H} 1$, $1 \mathrm{H} 4,2 \mathrm{H} 8,3 \mathrm{H} 25,3 \mathrm{H} 24$, and $3 \mathrm{H} 20$. Three strains-3H29, $3 \mathrm{H} 18$, and $1 \mathrm{H} 10$-demonstrated $<60 \%$ similarity with any of the other organisms and were separated from the tighter grouping, perhaps as major biotypes or subspecies. As was found in the case of the culture collection strains, the halophilic cocci were sufficiently different from the rods and thus formed a separate generic group, the third group.

A calculation of combined data sets, including both positive and negative matches (matching value calculation) and excluding the cocci and the three distinctly different strains, yielded the matrix shown in Fig. 8. The high similarity of the strains comprising the group $(>70 \%)$ was noted. This would indicate, then, that whereas there is some diversity in reaction to various 


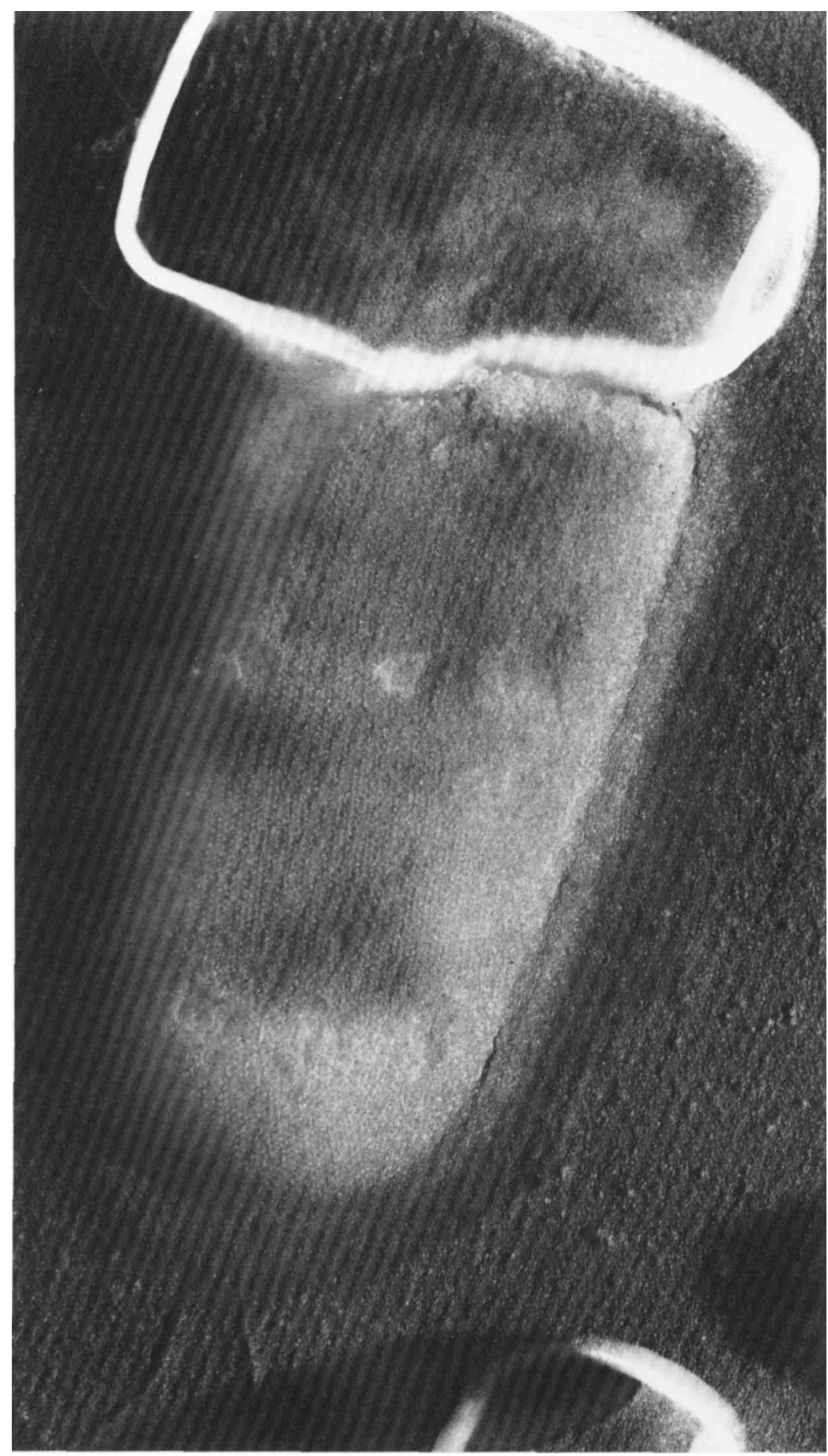

Fig. 5. Surface of an extremely halophilic rod, determined by electron microscopy. Halobacterium cutirubrum NRC 54001 (courtesy of D. J. Kushner); $\times 66,000$. 
TABLE 3. Feature frequencies of selected characteristics within a sample set of 47 strains of halophilic bacteria

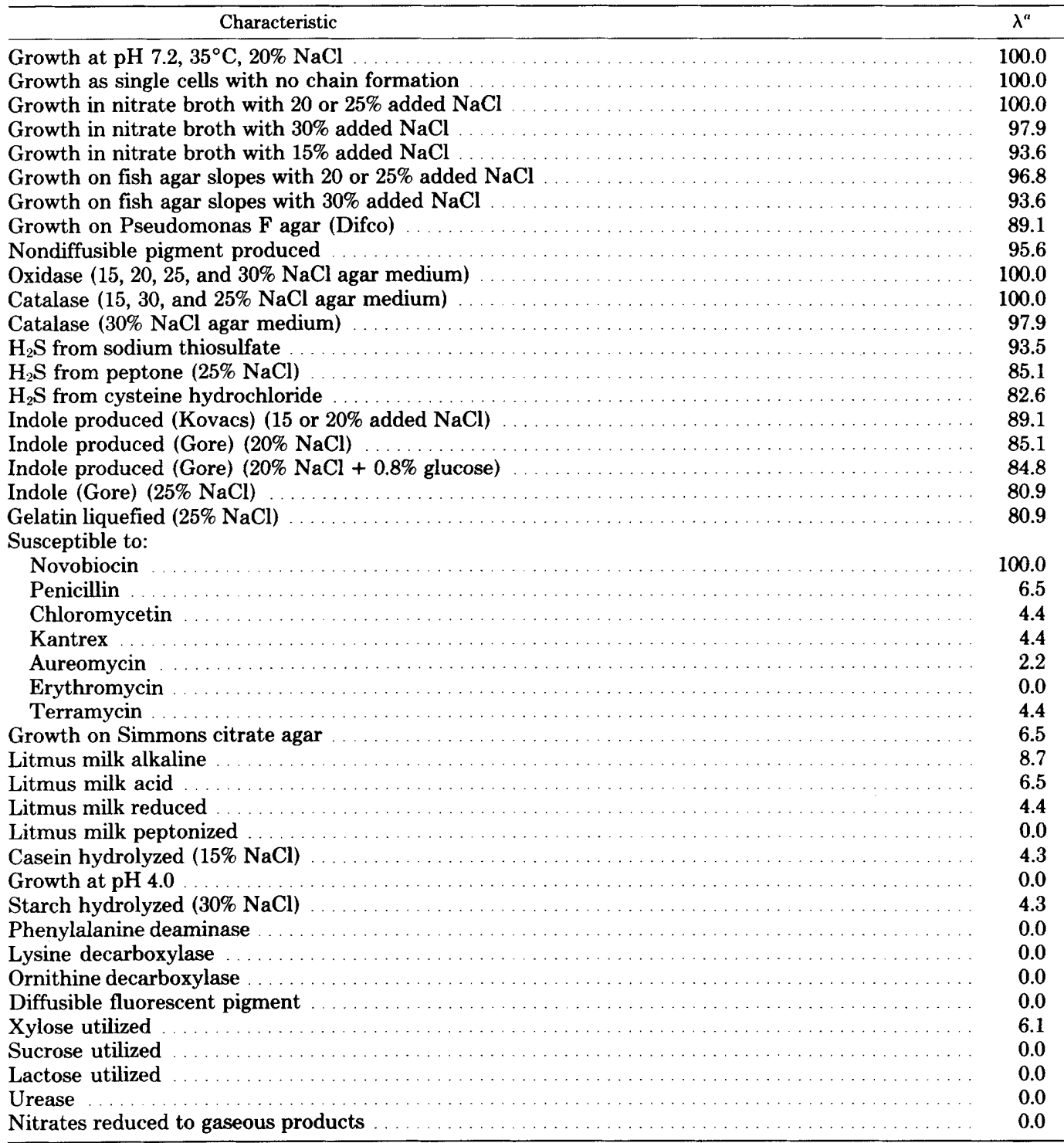

${ }^{a} \lambda$, Percentage of strains positive for feature tested (total sample $=47$ ).

biochemical tests, these differences are not sufficiently large to justify separation into several species; they do argue strongly, however, for biovar rank.

A comparison of the positions of the $H$. salinarium and $H$. cutirubrum strains in the two matrices shows that, based on positive matches alone, they can be separated, but when both positive and negative matches are included, the two organisms show $85 \%$ similarity.

The major groupings obtained were: the halotolerant strains, the culture collection strains, and the halophilic bacteria. A very tight cluster comprising 32 of the laboratory isolates was observed at 80 to $85 \% S$. A smaller group (isolates 104, 105, and 106) also formed at this same $S$ value, but these strains shared only 40 to $60 \%$ similarity to the other isolates. The remainder of the strains, including those recently isolated, were distributed throughout the matrix and did not show any substantial degree of intercalation. Strains labeled in the 900 series fell, for the most part, into two sections; the Bonaire strains were distributed into three portions of the matrix; and 


\begin{tabular}{|c|c|}
\hline Characteristic & $\lambda^{\prime \prime}$ \\
\hline \multicolumn{2}{|l|}{ Morphology: } \\
\hline Rods or rod-shaped & 100.0 \\
\hline Stout $(0.6$ to $1.0 \mu \mathrm{m})$ & 100.0 \\
\hline Occurring as single cells & 100.0 \\
\hline Occurring as paired cells & 60.0 \\
\hline Round-ended rod & 90.0 \\
\hline Tapered end .... & 53.3 \\
\hline Oval ........ & 3.3 \\
\hline Medium length $(0.6$ to $1.5 \mu \mathrm{m}) \ldots \ldots$ & 3.3 \\
\hline Short, slender rods & 0.0 \\
\hline Filaments formed . . & 0.0 \\
\hline Curved rods $\ldots \ldots \ldots \ldots \ldots \ldots \ldots \ldots$ & 0.0 \\
\hline Motile $\ldots \ldots \ldots \ldots \ldots \ldots \ldots \ldots \ldots$ & 23.3 \\
\hline \multicolumn{2}{|l|}{ Growth on agar: } \\
\hline Small colony $(<2 \mathrm{~mm})$ & 100.0 \\
\hline Convex ....... & 100.0 \\
\hline Entire edge & 100.0 \\
\hline Nondiffusible pigment formed & 100.0 \\
\hline Translucent . . . . . . . . . . . . & 89.7 \\
\hline Opaque .... & 10.3 \\
\hline \multicolumn{2}{|l|}{ Growth in broth: } \\
\hline Even turbidity & 100.0 \\
\hline Moderate turbidity & 93.1 \\
\hline Ring formed ...... & 3.5 \\
\hline Pellicle formed & 0.0 \\
\hline Granular & 0.0 \\
\hline \multicolumn{2}{|l|}{ Other growth characteristics: } \\
\hline Fish agar slopes $(20,25$, or $30 \% \mathrm{NaCl})$ & 100.0 \\
\hline$\ldots \ldots \ldots \ldots \ldots \ldots \ldots \ldots$ & 100.0 \\
\hline$\ldots \ldots \ldots \ldots \ldots \ldots \ldots \ldots$ & 82.8 \\
\hline$\ldots \ldots \ldots \ldots \ldots$ & 75.9 \\
\hline $\mathrm{pH} 4.5$ & 10.3 \\
\hline $\mathrm{pH} 4.0$ & 0.0 \\
\hline \multicolumn{2}{|l|}{ Biochemical characteristics: } \\
\hline Catalase $(15,20,25$, or $30 \% \mathrm{NaCl})$ & 100.0 \\
\hline Arginine dihydrolase & 100.0 \\
\hline Gelatin liquefied ( 25 or $30 \% \mathrm{NaCl}$ ) & 100.0 \\
\hline $\mathrm{H}_{2} \mathrm{~S}$ from peptone $(25$ or $30 \% \mathrm{NaCl})$ & 100.0 \\
\hline Indole $(25 \% \mathrm{NaCl})$ & 100.0 \\
\hline $\mathrm{H}_{2} \mathrm{~S}$ from sodium thiosulfate & 100.0 \\
\hline $\mathrm{H}_{2} \mathrm{~S}$ from cysteine hydrochloride & 89.7 \\
\hline Kovacs oxidase & 72.4 \\
\hline Casein hydrolyzed & 66.7 \\
\hline Lipase (Tween 60) . . . . . . & 17.2 \\
\hline (Tween 40) $\ldots \ldots \ldots$ & 13.8 \\
\hline (Tween 80) & 0.0 \\
\hline Milk peptonized & 13.8 \\
\hline Koser citrate. & 13.8 \\
\hline Simmons citrate & 3.5 \\
\hline Starch hydrolyzed $(15,20$, or $25 \% \mathrm{NaCl})$ & 3.3 \\
\hline Starch hydrolyzed $(30 \% \mathrm{NaCl}) \ldots \ldots$ & 0.0 \\
\hline Urease & 0.0 \\
\hline Glycerol utilized & 63.6 \\
\hline Glucose utilized & 43.3 \\
\hline \multicolumn{2}{|l|}{ Susceptible to: } \\
\hline Polymyxin B (300 U) & 69.0 \\
\hline Tetracycline $\ldots \ldots$ & 55.2 \\
\hline Dihydrostreptomycin & 43.3 \\
\hline Penicillin . . . . . . . . & 0.0 \\
\hline Chloromycetin & 0.0 \\
\hline Terramycin ... & 0.0 \\
\hline Erythromycin & 0.0 \\
\hline Kantrex ...... & 0.0 \\
\hline Aureomycin & 0.0 \\
\hline
\end{tabular}

${ }^{a} \lambda$, Percentage of strains positive for feature tested (total sample $=30$ ). 


\section{SIMILARITY VALUE (\% S)}

\begin{tabular}{|c|c|c|c|c|}
\hline o-4WV & 8 & ర & $\stackrel{\infty}{0}$ & ஜீ \\
\hline
\end{tabular}

A. 2 C (coloriessi

H. nalobium $P$

1. culirudrum 9

402

$N-8$

. nolobium 6.31 .10

$A-24$

$A-18$

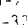

$S C-1$

SC -4

5

4

8. nalobium 6.31.

H. salinarium 10

B. nalobium 6. 31 . 6

$\mathrm{SC}-2$

B. nalobium 0.31 .

8. halobium 6.31 .4

B. nalobium 6.31 .2

8. nolobium 6.31 .3

B. nolobium 6.31 .9

Ps. cutirubra (Lochheadi

$N-3$

A-3IC icolorless

. gibbonsii $\mathrm{H45T}$

H. gibbonsii $\mathrm{H}_{45}$

. Mrapanicum

H. halobi um Delft

Ps. cutirubrum $\mathrm{H} 48$

Sarcina morrtane Delth

Micrococcus sp. H-

Sarcina gig ditea

Sarcina $\mathrm{SP}, \mathrm{H}-8$

Sarcino sp. $\mathrm{H}-2$

Sarcino fittoral is $\mathrm{H}-9$

$\mathrm{H}$. minureum $\mathrm{H} 24 \mathrm{~T}$

Micrococeus morrhuar Dolft

Sarcina sreenivasani

Sarcina morrtivae.

Micrococcus marrtivae (Dead Sea) Volcani

Micrococcus morrhude tDelft, Volcani

Sarcina morthuoe 9.5

Sarcina morthuae $M$

$N-4$

$N-5$

Sarcina littoralis (Lochhead) 8

A-31 (red)

$A-14$

D. halobium 6.31 .8

3-3

Sorcino sp. $\mathrm{H}-1$

(n)

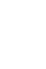

Micrococeus denitrificons

Micrococcus halodenitrificans 79

Empedobocter marismortui

vibrio costicolus (Inst. Pasteur)

Vibrio holodenitrificans

Vibrio costicolus 75

Ps. be iperinckii

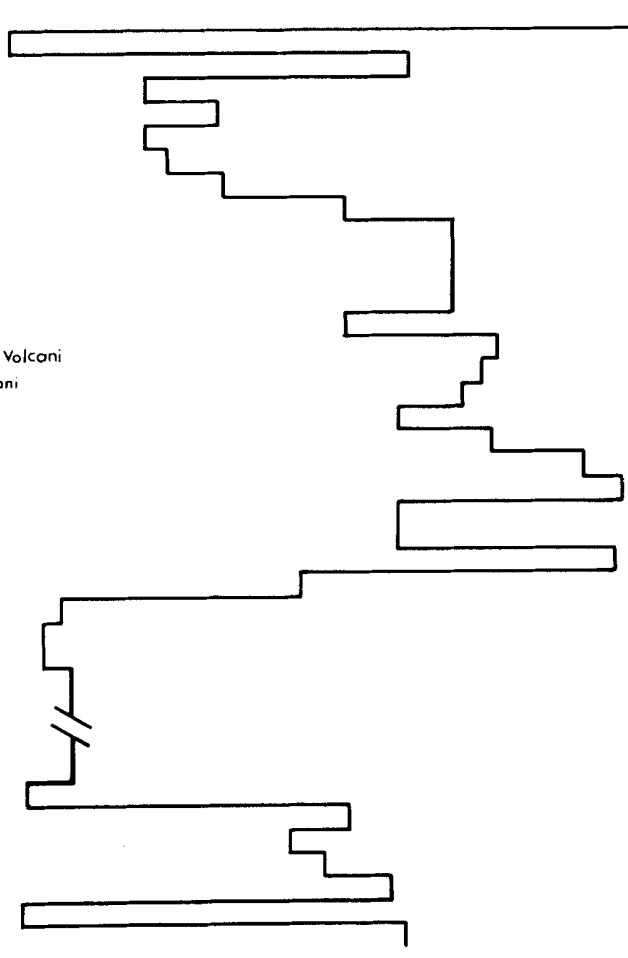

FIG. 6. Highest-linkage sorting for culture collection strains of halophilic bacteria included in this study. 
TABLE 5. Feature frequencies of characteristics studied for the halophilic micrococci

\begin{tabular}{|c|c|}
\hline Characteristic & $\lambda^{a}$ \\
\hline \multicolumn{2}{|l|}{ Morphology: } \\
\hline Ovals, spheres & 100.0 \\
\hline Stout $(0.6$ to $1.0 \mu \mathrm{m}$ in diameter $)$ & 100.0 \\
\hline 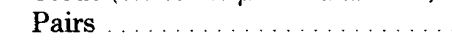 & 100.0 \\
\hline Motile & 0.0 \\
\hline
\end{tabular}

Growth on agar:

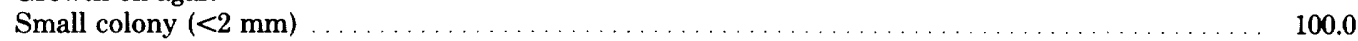

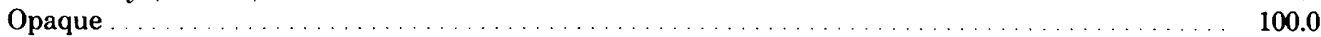

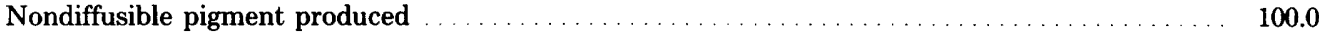

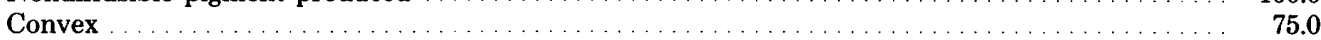

Growth in broth:

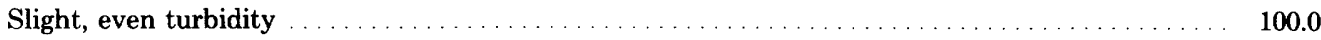

Other characteristics:

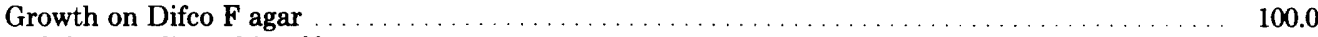

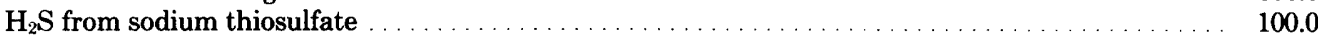

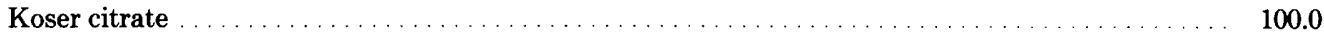

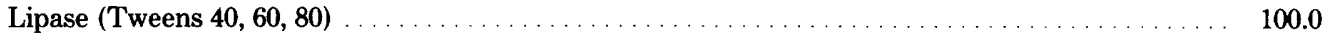

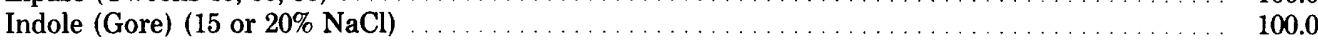

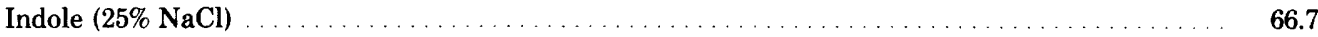

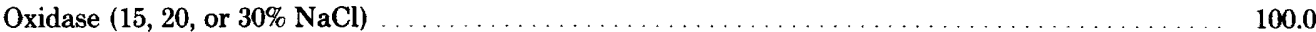

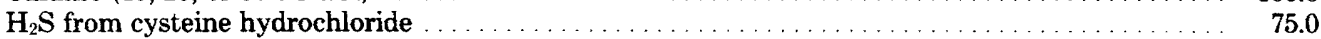

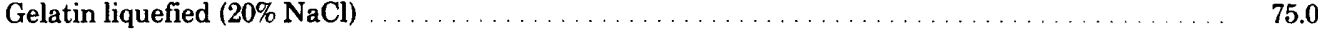

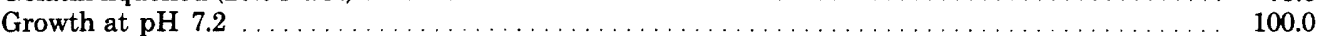

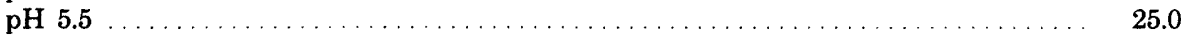

pH 8.0, 8.5 $\ldots \ldots \ldots \ldots \ldots \ldots \ldots \ldots \ldots \ldots$

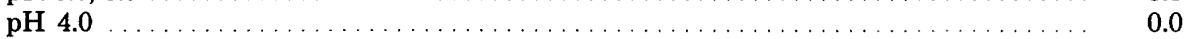

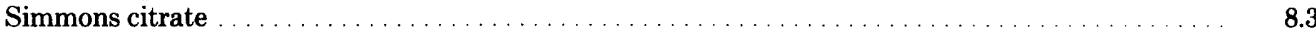

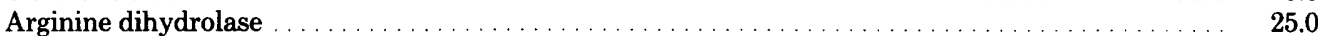

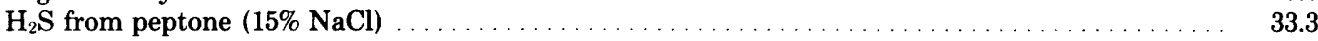

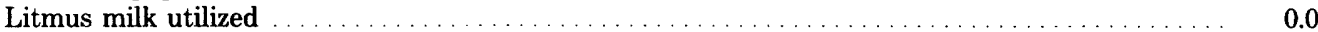

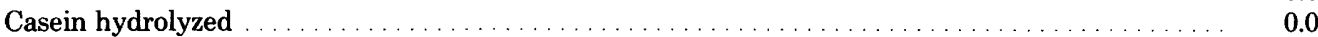

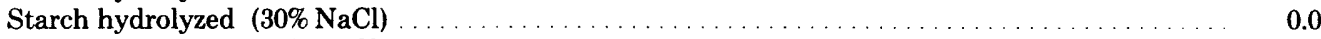

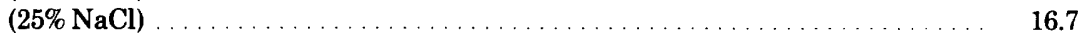

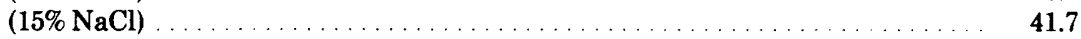

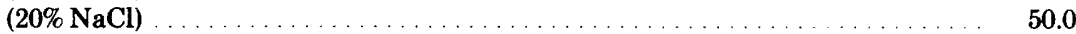

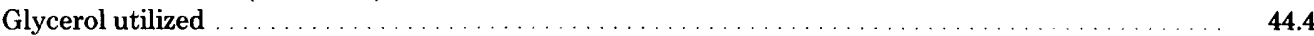

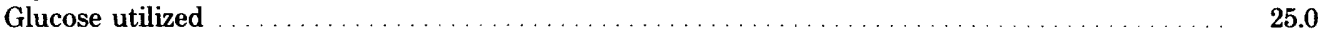

Susceptible to:

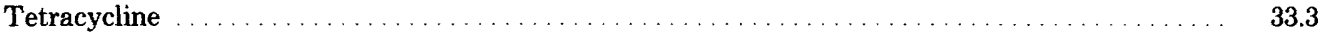

Polymyxin B . . . . . . . .

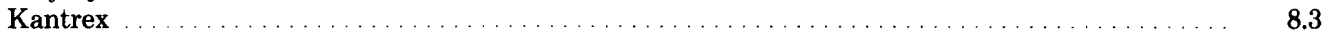

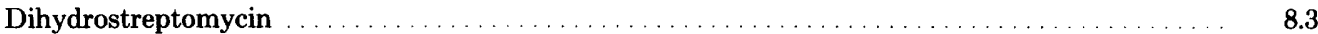

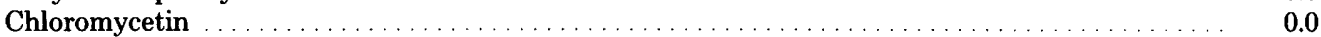

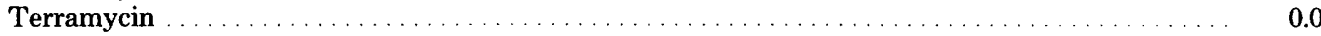

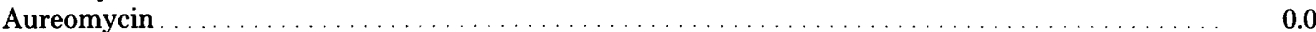

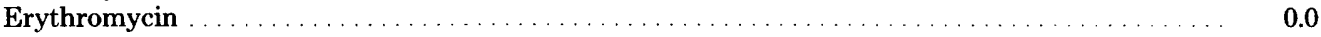

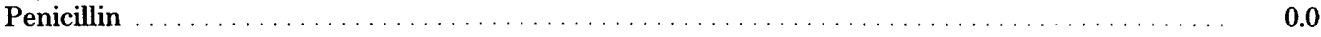

${ }^{a} \lambda$, Percentage of strains positive for feature tested (total sample $=42$ ).

strains labeled within the 100 series fell mainly in the major large cluster of related strains.

\section{DISCUSSION}

In an attempt to assess the homogeneity of a set of culture collection strains of halophiles, the method of Quadling and Colwell (32) was applied, in which the mean value of $\bar{N}_{s}$ was regarded as a measure of demonstrated homogeneity of the organisms. From Fig. 1, it was noted that two apparently separate clusters existed: the lower left-hand cluster, consisting predomi- 
nantly of cocci, and the upper right-hand one, consisting of halophilic rods. Upon closer inspection, however, strains $3,9,11,22,27$, and 28 sorted out by highest-linkage method $(8,9)$ with the group of rod-shaped organisms, and, conversely, strains $39,40,41,42,43$, and 44 sorted out with the cocci. Several explanations can be offered for the apparent inability of this plotting

TABLE 6. Feature frequencies of selected characteristics for 17 of the tested strains of halophilic bacteria

\begin{tabular}{|c|c|c|}
\hline \multirow{2}{*}{ Characteristic } & \multicolumn{2}{|c|}{$\lambda^{a}$} \\
\hline & Group 2 & Group 3 \\
\hline Gram-negative & 100.0 & 100.0 \\
\hline 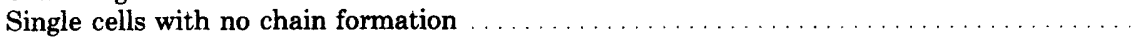 & 100.0 & 100.0 \\
\hline 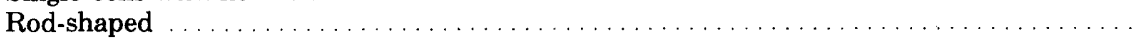 & 100.0 & 67.0 \\
\hline 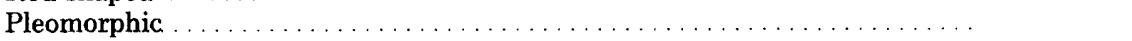 & 0.0 & 33.0 \\
\hline Red pigmentation regardless of medium & 25.0 & 100.0 \\
\hline 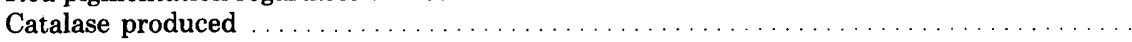 & 86.0 & 100.0 \\
\hline \multicolumn{3}{|l|}{ Growth at $30^{\circ} \mathrm{C}$ in: } \\
\hline 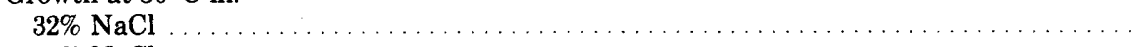 & 100.0 & 89.0 \\
\hline 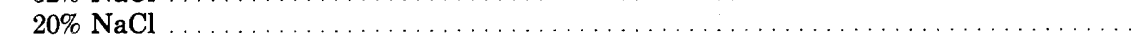 & 86.0 & 100.0 \\
\hline 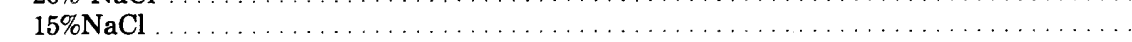 & 75.0 & 100.0 \\
\hline$\ldots \ldots \ldots \ldots \ldots \ldots \ldots \ldots \ldots$ & 75.0 & 56.0 \\
\hline$\ldots \ldots \ldots \ldots \ldots \ldots \ldots \ldots \ldots \ldots$ & 0.0 & 11.0 \\
\hline $4^{\circ} \mathrm{C}$ and $45^{\circ} \mathrm{C}$ are lethal regardless of salt concentration & 100.0 & 78.0 \\
\hline Growth at bottom of tube of thioglycolate medium $\ldots \ldots \ldots$ & 13.0 & 44.0 \\
\hline Cytochrome-oxidase positive $\ldots \ldots \ldots \ldots \ldots \ldots \ldots \ldots \ldots$ & 38.0 & 50.0 \\
\hline Motile ................. & 50.0 & 44.0 \\
\hline 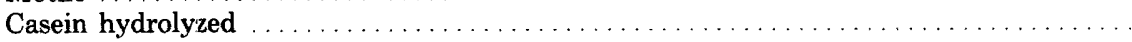 & 38.0 & 50.0 \\
\hline \multicolumn{3}{|l|}{ Growth in $20 \% \mathrm{NaCl}$ at $30^{\circ} \mathrm{C}$ at: } \\
\hline 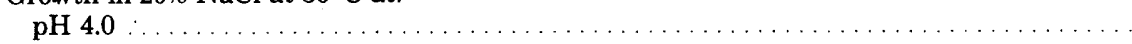 & 0.0 & 0.0 \\
\hline 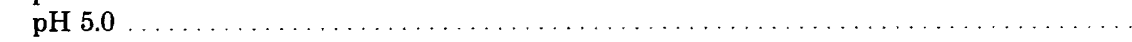 & 33.0 & 38.0 \\
\hline 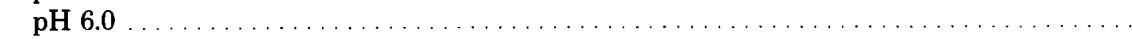 & 100.0 & 75.0 \\
\hline 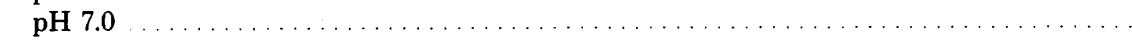 & 100.0 & 100.0 \\
\hline 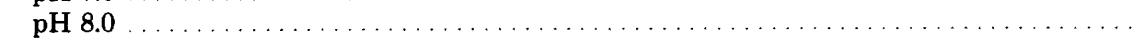 & 100.0 & 100.0 \\
\hline$\ldots \ldots \ldots \ldots \ldots \ldots \ldots \ldots$ & 75.0 & 13.0 \\
\hline Lysine-decarboxylase positive & 63.0 & 33.0 \\
\hline Ornithine-decarboxylase positive & 88.0 & 89.0 \\
\hline $0 \% \mathrm{NaCl}$ is lethal regardless of temperature & 100.0 & 100.0 \\
\hline 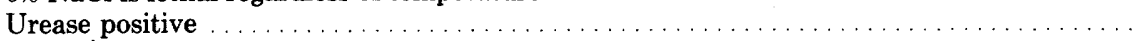 & 38.0 & 56.0 \\
\hline (1, & 13.0 & 0.0 \\
\hline 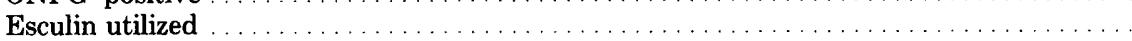 & 13.0 & 22.0 \\
\hline 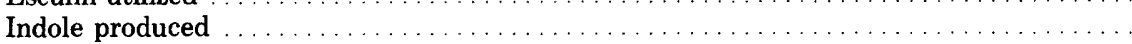 & 14.0 & 67.0 \\
\hline \multicolumn{3}{|l|}{ Susceptible to: } \\
\hline Penicillin G & 67.0 & 0.0 \\
\hline 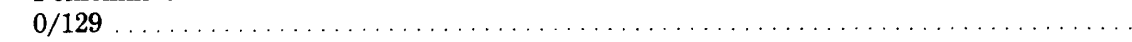 & 17.0 & 11.0 \\
\hline 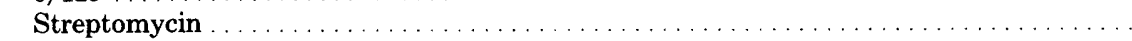 & 0.0 & 0.0 \\
\hline 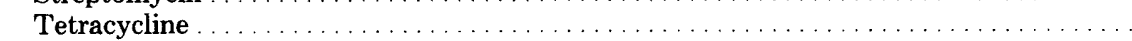 & 0.0 & 0.0 \\
\hline 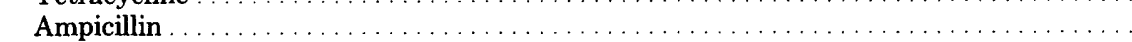 & 83.0 & 0.0 \\
\hline . & 13.0 & 0.0 \\
\hline \multicolumn{3}{|l|}{ Acid from: } \\
\hline Glucose & 0.0 & 0.0 \\
\hline (1, & 0.0 & 0.0 \\
\hline 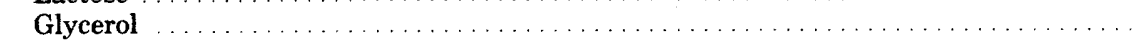 & 50.0 & 63.0 \\
\hline$\ldots \ldots \ldots \ldots \ldots \ldots \ldots \ldots \ldots \ldots$ & 0.0 & 0.0 \\
\hline$\ldots \ldots \ldots \ldots \ldots \ldots \ldots \ldots \ldots$ & 33.0 & 44.0 \\
\hline Sucrose & 0.0 & 11.0 \\
\hline Malonate utilization & 0.0 & 0.0 \\
\hline$\ldots \ldots \ldots \ldots \ldots \ldots \ldots \ldots \ldots$ & 38.0 & 0.0 \\
\hline Phenylalanine-deaminase positive & 0.0 & 0.0 \\
\hline Starch hydrolyzed ............ & 0.0 & 0.0 \\
\hline $\mathrm{H}_{2} \mathrm{~S}$ from cysteine. & 0.0 & 0.0 \\
\hline
\end{tabular}

${ }^{a} \lambda$, Percentage of strains positive for feature tested. Isolates comprising each group are: group 2-1H8, the strain of $H$. cutirubrum, 3H23, 3H31, 2H13, 3H22, 3H21, 3H16; group 3-the strain of $H$. salinarium, 3H27, $3 \mathrm{H} 28,2 \mathrm{H} 8,2 \mathrm{H} 7,1 \mathrm{H} 7,1 \mathrm{H} 16,1 \mathrm{H} 1,1 \mathrm{H} 4$.

${ }^{b} \mathrm{ONPG}, \alpha$-Nitrophenyl- $\beta$-D-galactopyranoside. 


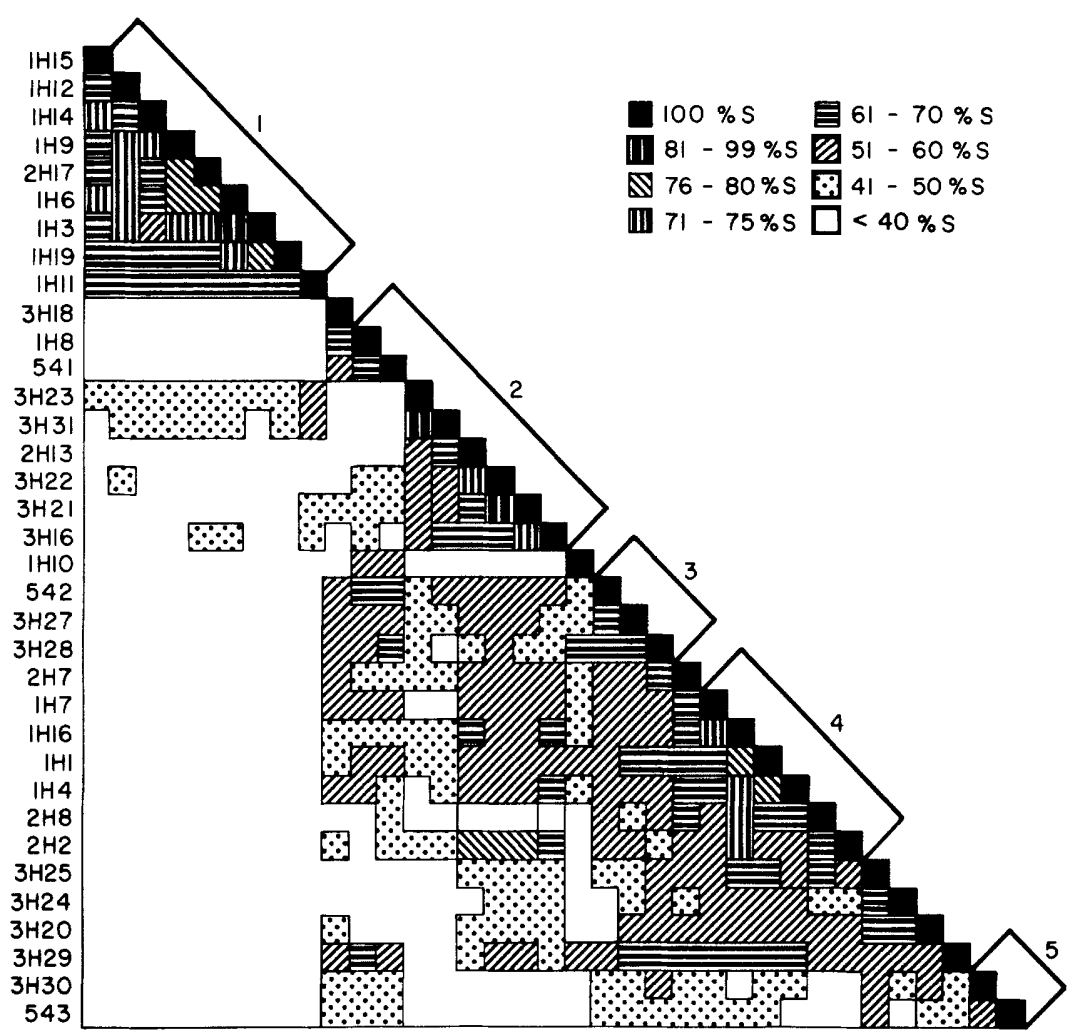

FIG. 7. Single-linkage analysis of positive characteristics of strains isolated from $>16 \%$ salt in a solar salt facility. See text for descriptions of groups.

method to distinguish absolutely the clusters formed by the highest-linkage method. First, there is the question of taxonomic distance between the groups of halophilic rods and cocci. On the basis of features studied in this report, the differences are of relatively small magnitude, although detectable. Second, and a correlate of the preceding, the features chosen and applied to the cultures in this study may not be sufficiently diverse and, therefore, not fully representative of the physiological and biochemical apparatus of the groups under survey. Either more features or more features of a different kind will be necessary for precisely distinguishing the groupings. In fact, the homogeneity of the group of rod-shaped strains appeared somewhat greater (Fig. 2) than that of the cocci (Fig. 3 ) when the data were plotted separately. Thus, combining data for non-homogeneous groups may contribute to the problem of cluster sepa- ration. This is partially observed in Fig. 8, where the data for culture collection strains and freshly isolated cultures were merged. The extremely halotolerant group I continued to be separated from the other isolates, and the various saltern isolates failed to be grouped, at any level greater than 50 to $65 \% S$, with the laboratory strains, implying a substantial degree of diversity within the generic relationship.

An earlier study of halotolerant strains of enterococci (Raj et al., Bacteriol. Proc., p. 21, 1964), micrococci, and staphylococci (Raj, Colwell, and Liston, unpublished data) indicated that some relationship between these taxa and the halophiles might exist. The combined data for these organisms and the halophiles, when computed and analyzed, revealed linkage $S$ values of about $40 \%$, much lower similarity values than would be expected if strong relationships between the groups were present. On the basis

FIG. 8. Similarity matrix of merged data sets for halophilic bacteria, including laboratory culture collection strains and recent isolates from a solar salt facility. See Table 1 for strain identity of culture collection strains (corresponding numbers in parentheses). The new isolates are labeled according to the designations in Table 2. 


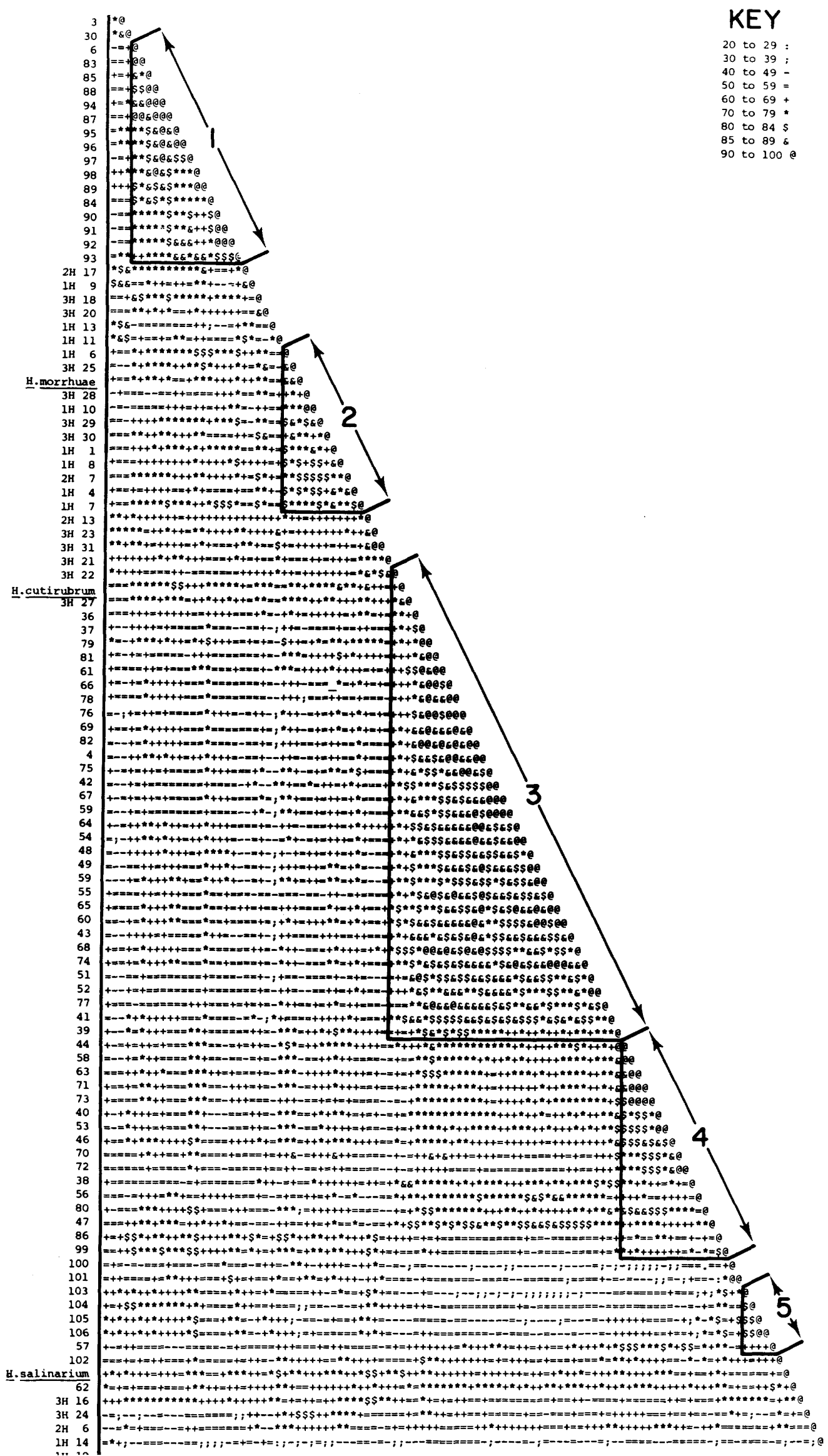


of data obtained from previous studies with other taxa of bacteria, significant interrelationships were discounted $(10,11,16)$.

Perhaps the strongest conclusion warranted by the data accumulated in this study is that only two genera appear to be substantiated: Halobacterium for the rod-shaped, gram-negative, halophilic bacteria, and a genus for the aerobic, halophilic cocci. For the latter, Halococcus Schoop has been suggested by other investigators as an appropriate generic name (24, 27) and, on the basis of the data reported in this paper, the aerobic, halophilic cocci are assigned to the genus Halococcus. This is in accord with the findings of Kocur and Hodgkiss (24).

Within the genus Halobacterium there appear to be, at best, two species: $H$. salinarium and $H$. cutirubrum. The distinction between these two species is not clear-cut, but the known differences are listed in Table 7.

The stability of these biochemical and cultural characteristics has been demonstrated by a 12 year lapse between the preparation of the two data sets involving $H$. cutirubrum and $H$. salinarium, i.e., comparison of culture collection strains and subsequent analyses of freshly isolated halophiles. When the data sets were compared, it was noted that over $90 \%$ agreement existed between the characteristics tested for the culture collection halophiles in 1964 and the freshly isolated halophiles examined in 1976. Differences that were noted arose, not unexpectedly, from some of the newer testing procedures, which were designed as improvements over the older methods for identification and classification of bacteria. For example, preliminary testing in 1975 indicated that most of the fresh isolates failed to grow in the standard decarboxylase test media. In addition, there seemed to be some degree of salt interference for these strains in the urease tests. Consequently, Patho-Tech Rapid ID test strips were used for these tests, with the result that the lysine and ornithine decarboxylases were positive for the fresh isolates (Table 7) and the urease test was negative (Table 7). The tests for gelatin hydrolysis and $\mathrm{H}_{2} \mathrm{~S}$ production differed markedly. The original set of 47 culture collection strains was positive for the oxidase reaction when tested by the procedure of Kovacs (25). The recent isolates were also positive for Kovacs' oxidase test but gave negative results for cytochrome oxidase when tested by the Patho-Tech strip method. The three reference strains included in the analyses of the fresh isolates gave similar results with the two methods. Thus, it is clear that the exact method for oxidase determination must be specified to avoid confusion.

Deoxyribonucleic acid homology studies, coupled with immunological and biochemical characterization, should provide data to conclude firmly whether the two currently recognized (18) species of Halobacterium are identical (31). In fact, it does appear from the data presented here and from the immunological studies of Zwilling et al. (39) that $H$. halobium strains and Pseudomonas cutirubra strains are identical. The strains of $H$. trapanicum and $H$. gibbonsii appear to be identical, but based on the immunological data, it is recommended that these be retained as biovars (39).

Within the group of halophilic cocci, the Sarcina littoralis, Halobacterium minuteum, and Sarcina sreenivasani strains are here considered to be members of Halococcus morrhuae (obj. syn.: Sarcina morrhuae; Micrococcus mor-

TABLE 7. Major differences between Halobacterium cutirubrum NRC 54001 and Halobacterium salinarium NRC 34002

\begin{tabular}{|c|c|c|}
\hline Characteristic & $\begin{array}{l}\text { H. cutirubrum } \\
\text { NRC } 54001\end{array}$ & $\begin{array}{l}\text { H. salinarium } \\
\text { NRC } 34002\end{array}$ \\
\hline Colony type & Translucent, red-orange, flat & Opaque, red, convex \\
\hline $\mathrm{O}_{2}$ requirement & Indifferent in thioglycolate & Aerobe in thioglycolate \\
\hline Lysine decarboxylase & - & + \\
\hline Urease & - & + \\
\hline $\mathrm{ONPG}^{a}$ & + & - \\
\hline Ornithine decarboxylase & - & + \\
\hline 0129 susceptible & + & - \\
\hline $\begin{array}{l}\text { Salt/temperature range for } \\
\text { growth }\end{array}$ & $\begin{array}{l}\text { Growth range } 25 \text { to } 45^{\circ} \mathrm{C} \text {, with } 20 \% \\
\text { and } 32 \% \text { salt }\end{array}$ & $\begin{array}{l}\text { Growth range } 25 \text { to } 32^{\circ} \mathrm{C} \text {, with } 15 \\
\text { to } 32 \% \text { salt }\end{array}$ \\
\hline Lethal salt/temperature range & $\begin{array}{l}4 \text { to } 15^{\circ} \mathrm{C} \text { at } 0 \text { to } 15 \% \mathrm{NaCl} ; 25,45 \\
30, \text { and } 37^{\circ} \mathrm{C} \text { at } 0 \text { to } 8 \% \mathrm{NaCl}\end{array}$ & $\begin{array}{l}45^{\circ} \mathrm{C} \text { at } 32 \% \mathrm{NaCl} ; 4^{\circ} \mathrm{C} \text { at } 0 \text { to } 15 \% \\
\mathrm{NaCl} ; 15,25,30, \text { and } 37^{\circ} \mathrm{C} \text { at } 0 \\
\text { to } 8 \% \mathrm{NaCl} ; 45^{\circ} \mathrm{C} \text { at } 0 \text { to } 20 \% \\
\mathrm{NaCl}\end{array}$ \\
\hline Carotenoid analysis & $\begin{array}{l}\text { Very complex carotenoids detect- } \\
\text { able }\end{array}$ & $\begin{array}{c}\text { Relatively simple carotenoids } \\
\text { present }\end{array}$ \\
\hline
\end{tabular}

${ }^{a}$ ONPG, $o$-Nitrophenyl- $\beta$-D-galactopyranoside. 
rhuae). The data for the moderate halophiles indicate that the strains of $\boldsymbol{M}$. denitrificans, $\boldsymbol{M}$. halodenitrificans, E. marismortui, $V$. costicolus, and $P$. beijerinckii are separate entities.

The moderate halophiles, in general, differed from the extreme halophiles by the inability of the former to produce indole, to reduce nitrates to nitrites, to produce gelatinase, and to hydrolyze casein. Furthermore, the moderate halophiles were able to reduce litmus milk and to produce abundant growth at $40^{\circ} \mathrm{C}$ or in $\mathrm{NaCl}$ concentrations $<8 \%$, and they laciked pigmentation. This plexus of features is concluded to be sufficiently great to warrant separation at the generic level.

The biochemical reactions of the halophilic bacteria have been shown to depend on the salt concentration of the medium (18), and certain reactions, such as indole production and gelatin hydrolysis, are directly related to the concentration of salt in the test medium. This is a noteworthy observation, for the effect of salt on the enzymes of moderate and extreme halophiles can be dramatic. The enzymes of Pseudomonas salinaria (Lochhead's original designation for strains 9 and 10 from salted buffalo hides) and of extreme halophiles demonstrate this phenomenon, whereas only a few of the enzymes of the moderate halophiles have been found to be truly halophilic. It is significant that one of the halophilic enzymes of the moderately halophilic bacteria is cytochrome oxidase, an enzyme involved in ionic transfer (27).

Kocur and Hodgkiss (24) amended the description of the genus Halococcus and its single species, $H$. morrhuae (Farlow 1880) Kocur and Hodgkiss. Strain CCM 537 (=ATCC 17082= NCMB 787) was designated the neotype strain of $H$. morrhuae (24).

Halobacterium Elazari-Volcani 1957 is the type genus of Halobacteriaceae Gibbons 1974. Halobacterium salinarium (Harrison and Kennedy) Elazari-Volcani 1957, 208 (basionym: Pseudomonas salinaria Harrison and Kennedy 1922 ) is the type species of the genus (18). Since there is no type or neotype strain, NRC 34002 (ATCC 33171) is here proposed as the neotype strain of $H$. salinarium. This strain has the characters (see Table 8) as given in the original description of this organism by Harrison and Kennedy (20).

Halobacterium cutirubrum (Lochhead) Elazari-V'olcani 1957, 209 (basionym: Serratia cutirubra Lochhead 1934, 275) was regarded by Gibbons (1974; ref. 18) as a subjective synonym of $H$. salinarium; however, it is here regarded as a separate species on the basis of the results of this study. $\boldsymbol{H}$. cutirubrum NRC 34001 (ATCC

TABLE 8. Comparison of characteristics for $H$. salinarium NRC 34002 with those recorded for Pseudomonas salinaria

\begin{tabular}{|c|c|}
\hline $\begin{array}{l}\text { H. salinarium } \\
\text { NRC } 34002\end{array}$ & $\begin{array}{c}\text { Serratia (Pseudomonas) } \\
\text { salinaria }{ }^{a} \\
\text { strain } 91-\mathrm{R} 6\end{array}$ \\
\hline $\begin{array}{l}\text { Gram-negative, pleomorphic rods, motile by means of } \\
\text { a single polar flagellum }\end{array}$ & $\begin{array}{l}\text { Gram-negative, highly pleomorphic, long rods or as } \\
\text { small and large cocci, motile }\end{array}$ \\
\hline Cells occur as single or pairs & Does not grow without added salt; growth in 16 to \\
\hline Growth in 15 to $32 \% \mathrm{NaCl}$ at $37^{\circ} \mathrm{C}$ and at $23^{\circ} \mathrm{C}$ & $35 \% \mathrm{NaCl}$ at $37^{\circ} \mathrm{C}$ and at $22^{\circ} \mathrm{C}$ \\
\hline Colonies are opaque, entire, and red pigmented & Red colonies \\
\hline No growth at concentrations of $\mathrm{NaCl}<15 \%$ & $\begin{array}{l}\text { No growth at }<15 \% \text { salt; optimum growth between } 28 \\
\text { and } 32 \%\end{array}$ \\
\hline Carbohydrates not fermented & No acid or gas from carbohydrates \\
\hline Not tested & Optimum temperature of growth, $42^{\circ} \mathrm{C}$ \\
\hline Maximum temperature of growth, 45 to $46^{\circ} \mathrm{C}$ & Maximum temperature of growth, $46^{\circ} \mathrm{C}$ \\
\hline $\begin{array}{l}\text { Minimum growth temperature depends on salt pres- } \\
\text { ent in the medium; growth observed at } 15^{\circ} \mathrm{C} \text { in } 20 \\
\text { to } 32 \% \mathrm{NaCl} \text {, survival in } 20 \text { to } 32 \% \mathrm{NaCl} \text { at } 4^{\circ} \mathrm{C}\end{array}$ & Minimum temperature of growth, $10^{\circ} \mathrm{C}$ \\
\hline Not tested & Thermal death time, $65^{\circ} \mathrm{C}, 10 \mathrm{~min}$ \\
\hline Obligate aerobe & Obligate aerobe \\
\hline Not tested & $\begin{array}{l}\text { Does not grow with } \mathrm{KNO}_{3} \text { or } \mathrm{NH}_{3} \mathrm{Cl} \text { as the source of } \\
\text { nitrogen }\end{array}$ \\
\hline Grows in peptone medium & Will grow in peptone \\
\hline Growth at pH 5.0 to 8.0 & Growth at pH 5.6 to 8.6 , optimum pH 6.0 \\
\hline Not tested & Not pathogenic in rabbits \\
\hline Poor growth in liquid media & Little or no growth in liquid media \\
\hline Nitrates generally not reduced & Does not reduce nitrates \\
\hline Starch not hydrolyzed & Does not hydrolyze starch \\
\hline Casein not digested & Not tested \\
\hline
\end{tabular}

${ }^{a}$ Harrison and Kennedy, 1922 (20) and Lochhead, 1934 (30). 
TABLE 9. Comparison of characteristics for H. cutirubrum NRC 34001 with Serratia cutirubra

\begin{tabular}{|c|c|}
\hline $\begin{array}{l}\text { H. cutirubrum } \\
\text { NRC } 34001\end{array}$ & $\begin{array}{l}\text { Serratia cutirubra } \\
\quad 63-\mathrm{R} 2\end{array}$ \\
\hline $\begin{array}{l}\text { Pleomorphic rod, also occurring as oval and coccoid } \\
\text { cells }\end{array}$ & $\begin{array}{l}\text { Pleomorphic rod, also occurring as oval and coccoid } \\
\text { forms }\end{array}$ \\
\hline Rods 1.5 to $8.0 \mu \mathrm{m}$ long by 0.6 to $1.0 \mu \mathrm{m}$ wide & Rods 1.5 to $8.0 \mu \mathrm{m}$ long by 0.7 to $1.4 \mu \mathrm{m}$ wide \\
\hline Motile by single polar flagellum & Motile in young culture with one polar flagellum \\
\hline No spores produced & No spores produced \\
\hline Gram negative & Gram negative \\
\hline Obligate aerobe & Obligate aerobe \\
\hline Requires salt, growing in 20 to $32 \% \mathrm{NaCl}$ & $\begin{array}{l}\text { Obligate halophile, growing in } 20 \% \mathrm{NaCl} \text { to saturation, } \\
\text { best from } 28 \text { to } 32 \%\end{array}$ \\
\hline No growth without added salt & No growth on ordinary media \\
\hline Poor growth in liquid media & Little or no growth in liquid media with salt \\
\hline Grows on fish salt agar & $\begin{array}{l}\text { Grows on milk-salt agar or fish salt agar; round, } \\
\text { reddish, convex, glistening }\end{array}$ \\
\hline Grows at $37^{\circ} \mathrm{C}$ & Optimum temperature, $37^{\circ} \mathrm{C}$ \\
\hline Liquefies gelatin & Liquefies gelatin \\
\hline Digests casein & Digests casein \\
\hline Produces ammonia from peptone & Produces ammonia \\
\hline Produces hydrogen sulfide & Produces hydrogen sulfide \\
\hline Nitrates not reduced & Nitrates not reduced \\
\hline Indole production variable, depending on medium & Indole not formed \\
\hline No starch hydrolysis & Diastase negative \\
\hline Carbohydrates not fermented & No fermentation of carbohydrates \\
\hline Not tested & Produces reddening on salted calf hide \\
\hline
\end{tabular}

${ }^{a}$ Lochhead, $1934(30)$.

33170 ) is here proposed as the neotype strain for the species. The characters of this strain (see Table 9) are in accord with those given by Lochhead (30) when he first named and described this organism.

Preliminary studies of six of the more recently isolated strains, in addition to the reference strains, show that the bacteriorhodopsin membrane (purple membrane) is associated with members of the H. cutirubrum group (Fig. 7) (L. A. Kiefer and C. D. Litchfield, unpublished data). Cultures were grown in the medium of Sehgal and Gibbons (33) at $30^{\circ} \mathrm{C}$ under continuous illumination of $1076 \mathrm{~lx}$. Membrane isolations (22) showed a typical purple membrane in $H$. cutirubrum strains $1 \mathrm{H} 8,3 \mathrm{H} 24$, and $1 \mathrm{H} 10$, whereas the complex mixture of red membrane components was isolated from $H$. salinarium strains $3 \mathrm{H} 18,1 \mathrm{H} 1$, and $2 \mathrm{H} 7$. These findings support separate species status for $H$. salinarium and $H$. cutirubrium and the inclusion of Halobacterium halobium strains in the latter species.

The results of the analyses described here suggest certain relationships between and within the groups of halophilic bacteria that support, in general, the taxonomy of the family Halobacter. iaceae presented in the eighth edition of Bergey's Manual (18). More extensive investigation of both the phenotype and the genotype, the latter via nucleic acid reassociation analyses, should prove useful for further resolution of the systematics of these fascinating microorganisms.

\section{ACKNOWLEDGMENTS}

This investigation was supported in part by grants GB 1623 and GB 18274 from the National Science Foundation and by contract N00014-69A-0220-0006 between the Office of Naval Research and Georgetown University. Additional support was provided by International Salt Co., Clarks Summit, $\mathrm{Pa}$.

We express our gratitude to C. Quadling for advice during the course of the work and to Margaret Gorman for excellent technical assistance. Data processing assistance was provided by Marcia Yuter Metzner, Brian Austin, and Elaine Krichevsky. G. B. Chapman and D. Kushner provided assistance in preparation of the electron micrographs. Donald Kronish of Warner-Lambert kindly supplied the Patho-Tech test strips used in this project. We are indebted to $H$. D. Hatt of the American Type Culture Collection for advice concerning the designation of the neotype strains.

\section{REPRINT REQUESTS}

Address reprint requests to: Dr. R. R. Colwell, Department of Microbiology, University of Maryland, College Park, MD 20742.

\section{LTERATURE CITED}

1. Abram, D., and N. E. Gibbons. 1960. Turbidity of suspensions and morphology of red halophilic bacteria as influenced by sodium chloride concentration. Can. J. Microbiol. 6:535-543.

2. Baxter, R.M. 1960. Carotenoid pigments of halophilic bacteria. Can. J. Microbiol. 6:417-424.

3. Board, R. G., and A. J. Holding. 1960. The utilization of glucose by aerobic gram-negative bacteria. J. Appl. Bacteriol. 23:xi.

4. Boring, J., D. J. Kushner, and N. E. Gibbons. 1963. Specificity of the salt requirement of Halobacterium cutirubrum. Can. J. Microbiol. 9:143-154.

5. Breed, R. S., E. G. D. Murray, and N. R. Smith (ed.). 1957. Bergey's manual of determinative bacteriology, 7th ed. The Williams and Wilkins Co., Baltimore.

6. Brown, H. J., and N. E. Gibbons. 1955. The effect of 
magnesium, potassium and iron on the growth and morphology of red halophilic bacteria. Can. J. Microbiol. 1:486-494.

7. Colwell, R. R. 1963 . Computer programs. Taxometrics no. 3 , p. 1-3.

8. Colwell, R. R. 1964. A study of features used in the diagnosis of Pseudomonas aeruginosa. J. Gen. Microbiol. $37: 181-194$.

9. Colwell, R. R., and J. Liston. 1961. Taxonomic relationships among the pseudomonads. J. Bacteriol. 82:1-14.

10. Colwell, R. R., and M. Mandel. 1965. Adansonian analysis and deoxyribonucleic acid base composition of Ser. ratia marcescens. J. Bacteriol. 89:454-461.

11. Colwell, R. R., M. Mandel, and H. Raj. 1967. The taxonomy of enterococci. Can. J. Microbiol. 13:917-919.

12. Colwell, R. R., and C. Quadling. 1962. Miniature tube tests in diagnostic bacteriology. Can. J. Microbiol. 8: 813-816.

13. Dussault, H. P. 1955. An improved technique for staining red halophilic bacteria. J. Bacteriol. 70:484-485.

14. Ewing, W. H. 1962. Enterobacteriaceae. Biochemical methods for group differentiation. U.S. Department of Health, Education and Welfare, Center for Disease Control, Atlanta.

15. Gibbons, N. E. 1936. Bacteria associated with the reddening of salt fish. J. Fish Res. Board Can. 3:70-76.

16. Gibbons, N. E. 1957. The effect of salt concentration on the biochemical reactions of some halophilic bacteria. Can. J. Microbiol. 3:249-255.

17. Gibbons, N. E. 1958. The effect of salt on the metabolism of halophilic bacteria, p. 69-77. In B. P. Eddy (ed.), The microbiology of fish and meat curing brines. Proc. Intern. Symp. Food Microbiol., 2nd, Cambridge, 1957. Her Majesty's Stationery Office, London.

18. Gibbons, N. E. 1974. Halobacteriaceae, p. 269-273. In R. E. Buchanan and N. E. Gibbons (ed.), Bergey's manual of determinative bacteriology, 8 th ed. The Williams and Wilkins Co., Baltimore.

19. Gibbons, N. E., and J. I. Payne. 1961. Relation of temperature and sodium chloride concentration to growth and morphology of some halophilic bacteria. Can. J. Microbiol. 7:483-489.

20. Harrison, F. C., and M. E. Kennedy. 1922. The red discoloration of cured codfish. Trans. R. Soc. Can. Sect. 5 16:101-152.

21. Holding, A. J., and J. G. Collee. 1971. Routine biochemical tests, p. 1-33. In J. R. Norris and D. W. Ribbons (ed.), Methods in microbiology, vol. 6A. Academic Press Inc., New York.

22. Kelly, M., S. Norgard, and S. Liagen-Jensen. 1970. Bacterial Carotenoids. XXXI. C-50 carotenoids v. carotenoids of Halobacterium salinarium, especially bacterioruberin. Acta Chem. Scan. 24:2169-2182.

23. Klebahn, H. 1919. Die Schädlings des Klippfisches. Mitt. Inst. Allgem. Botanik Hamburg 4:11-69.

24. Kocur, M., and W. Hodgkiss. 1973. Taxonomic status of the genus Halococcus Schoop. Int. J. System. Bacteriol. 23: 151-156.

25. Kovacs, N. 1956. Identification of Pseudomonas pyocy. anea by the oxidase reaction. Nature (London) 178: 703.

26. Kushner, D. J. 1964. Lysis and dissolution of cells and envelopes of an extremely halophilic bacterium. J. Bacteriol. 87:1147-1156.

27. Larsen, H. 1963. Halophilism, p. 297-342. In I. C. Gunsalus and R. Y. Stanier (ed.), The bacteria: a treatise on structure and function, vol. IV: The physiology of growth. Academic Press Inc., New York.

28. Larsen, H. 1967. Biochemical aspects of extreme halophilism, p. 97-132. In A. H. Rose and J. F. Williams (ed.), Advances in microbial physiology, vol. 1. Academic Press Inc., New York.

29. LeDantec, A. 1891. Etude de la morue rouge. Ann. Inst. Pasteur 5:656-667.

30. Lochhead, A. G. 1934. Bacteriological studies on the red discoloration of salted hides. Can. J. Res. 10:275-286.

31. Moore, R. L., and B. J. McCarthy. 1969. Base sequence homology and renaturation studies of the deoxyribonucleic acid of extremely halophilic bacteria. J. Bacteriol. 99:255-262.

32. Quadling, C., and R. R. Colwell. 1964. The use of numerical methods in characterizing unknown isolates, p. 151-161. In Developments in Industrial Microbiology, vol. 5, Proc. Soc. Ind. Microbiol., 20th General Meeting, Amherst, 1963. American Institute for Biological Sciences, Washington, D.C.

33. Sehgal, S. N., and N. E. Gibbons. 1934. Effect of some metal ions on the growth of Halobacterium cutirubrum. Can. J. Microbiol. 6:165-169.

34. Sierra, G. 1957. A simple method for the detection of lipolytic activity of microorganisms and some observations on the influence of the contact between cells and fatty substrates. Antonie van Leeuwenhoek J. Microbiol. Serol. 23:15-22.

35. Silvestri, L., M. Turri, L. R. Hill, and E. Gilardi. 1962. A quantitative approach to the systematics of Actinomycetes based on overall similarity, p. 333-360. In Microbial Classification, Soc. Gen. Microbiol. Symp., 12th. Cambridge University Press, London.

36. Skerman, V. B. D. 1967. A guide to the identification of the genera of bacteria, 2nd ed. The Williams and Wilkins Co., Baltimore.

37. Society of American Bacteriologists, 1957. Manual of microbiological methods. McGraw-Hill Book Company, Inc., New York.

38. Takahashi, I., and N. E. Gibbons. 1957. Effect of salt concentration on the extracellular nucleic acids of $\mathbf{M i}$. crococcus halodenitrificans. Can. J. Microbiol. 3:687694.

39. Zwilling, B. S., R. Rowen, and G. Stotzky. 1969. Immunological relationships among some species of extremely halophilic bacteria. J. Bacteriol. 98:384-387. 